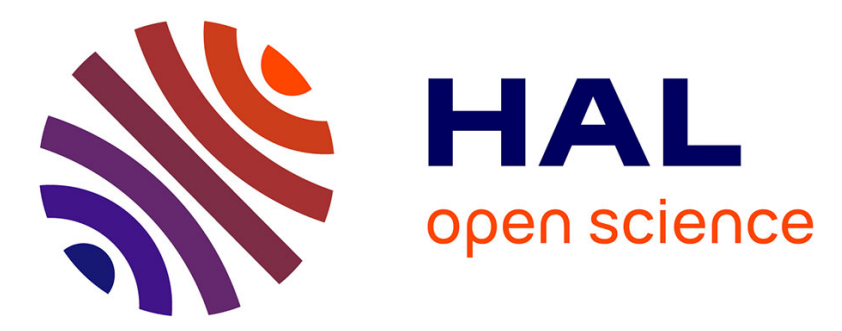

\title{
Acquisition experience and director remuneration
}

\author{
Addis Gedefaw Birhanu, Philipp Geiler, Luc Renneboog, Yang Zhao
}

\section{To cite this version:}

Addis Gedefaw Birhanu, Philipp Geiler, Luc Renneboog, Yang Zhao. Acquisition experience and director remuneration. Journal of International Financial Markets, Institutions and Money, 2021, FORTH. hal-03265164

\section{HAL Id: hal-03265164 \\ https://hal.science/hal-03265164}

Submitted on 19 Jun 2021

HAL is a multi-disciplinary open access archive for the deposit and dissemination of scientific research documents, whether they are published or not. The documents may come from teaching and research institutions in France or abroad, or from public or private research centers.
L'archive ouverte pluridisciplinaire HAL, est destinée au dépôt et à la diffusion de documents scientifiques de niveau recherche, publiés ou non, émanant des établissements d'enseignement et de recherche français ou étrangers, des laboratoires publics ou privés. 


\title{
Acquisition experience and director remuneration
}

\author{
Addis Gedefaw Birhanu ${ }^{a}$, Philipp Geiler ${ }^{\mathrm{b}}$, Luc Renneboog ${ }^{\mathrm{c}, *}$, Yang Zhao ${ }^{\mathrm{d}}$ \\ ${ }^{a}$ EMlyon business school, 69130 Ecully, France \\ ${ }^{\mathrm{b}}$ Willis Towers Watson, Ulmenstraße 30, 60325 Frankfurt, Germany \\ ${ }^{\mathrm{c}}$ Tilburg University, POBox 90153, 5000 LE Tilburg, The Netherlands \\ ${ }^{\mathrm{d}}$ University of Liverpool Management School, Chatham St, Liverpool L69 7ZH, UK
}

\section{A R T I C L E I N F O}

\section{Article history:}

Received 22 November 2020

Accepted 9 May 2021

Available online $\mathrm{xxxx}$

\section{Keywords:}

M\&A

Takeovers

Mergers

Remuneration contracting

Compensation

Experience

Human capital

Skills

\begin{abstract}
A B S T R A C T
We investigate whether acquisition experience of executive and non-executive directors is priced in their remuneration contracts. Acquisition experience generates a contractual premium, and the relative size of this premium is higher for non-executive directors than for executives. Only a director's track record related to past successful acquisitions is priced. Acquisition experience of a director is not remunerated if this type of experience is already abundantly present in the firm through the firm's past acquisition record (substitution effect). We verify the results by examining potential endogeneity concerns, by analyzing a broad set of measures of acquisition experience (such as industry-specific, broad or international experience, experience on a target's board), and by ruling out alternative explanations (such as a director's general skills level or reputation, the CEO's power and delegation attitude, and the firm's corporate governance quality).
\end{abstract}

(c) 2021 The Authors. Published by Elsevier B.V. This is an open access article under the CC BY-NC-ND license (http://creativecommons.org/licenses/by-nc-nd/4.0/).

\section{Introduction}

The experience that executive and non-executive directors accumulate by working in specific positions within firms and possibly across industries is one of the most important dimensions of their human capital (Mackey et al., 2014; Zattoni and Cuomo, 2010). As such, firm and industry experience remains an important predictor of pay (Custódio et al., 2013; Datta and Iskandar-Datta, 2014). Studies show that non-executive directors' effort, experience, and resourcefulness contribute significantly to their remuneration (Bugeja et al., 2016; Fedaseyeu et al., 2018). Also, general managerial human capital that is transferable across firms and industries leads to a higher pay premium for CEOs, more so than specialized skills (Custódio et al., 2013). This finding is stronger when CEOs with general managerial skills are hired from outside the firm rather than when they are internally promoted (Brockman et al., 2016). Overall, these studies suggest that variance in pay is primarily driven by differences in human capital that individuals accumulate over their career path.

However, there is a paucity in the literature on if and why directors are paid differently across and within firms for a similar task-specific human capital. We address this question by focusing on a task-specific experience, namely that of M\&A experience, and investigate whether this experience is priced in the remuneration contract of directors. Throughout the paper, we use 'directors' to refer to both executive and non-executive directors ${ }^{1}$.

\footnotetext{
* Corresponding author at: Tilburg University, POBox 90153, 5000 LE Tilburg, The Netherlands.

E-mail addresses: birhanu@em-lyon.com (A.G. Birhanu), Philipp.Geiler@willistowerswatson.com (P. Geiler), Luc.Renneboog@tilburguniversity.edu (L. Renneboog), yang.zhao3@liverpool.ac.uk (Y. Zhao).

${ }^{1}$ As this paper is on UK directors, we use UK terminology. According to the UK corporate governance code, an executive director is a top manager (officer) who is a member of the board of directors. A non-executive director (often referred to as "director" in the US) is a board member who does not hold an executive position in the firm.
} 
This task-specific human capital deserves attention for the following reasons. First, takeovers are complex operations that require expertise to identify an appropriate target, undertake the required due diligence, assess the potential synergistic value contribution of the target, decide on the level of integration, pursue a negotiation process, and, upon a successful conclusion, raise the acquisition financing and implement the complete or partial integration of the target into the acquirer (Hambrick et al., 2015; Hillman and Dalziel, 2003). Although acquisitions are undertaken with the support of investment banks, takeover lawyers, and due diligence and audit firms, directors remain responsible for overseeing the takeover process, for advice to shareholders, and for the ultimate decision. Second, takeovers are ubiquitous and salient strategic activity as hardly any firm is not exposed to a takeover bid or making such bids itself. For example, in 2018, the size of global M\&A deals exceeded 5.3 trillion USD, of which 29\% stem from deals targeting companies in Western Europe (Geiler and Birhanu, 2020). More than ninety percent of US-listed firms engaged in acquisitions from 1990 to 2000 with a median of eight acquisitions (Netter et al., 2011). About 75\% of firms can even be called serial acquirers, taking over several firms on a yearly basis (Renneboog and Vansteenkiste, 2019). Third, acquisitions typically require large investments that profoundly affect a company's growth, value creation, and long-term prospects (Renneboog and Vansteenkiste, 2019). Fourth, despite their capital intensive nature, unsuccessful acquisitions are far from rare (Cartwright and Schoenberg, 2006; King et al., 2004); the combined cumulative abnormal returns (CARs) of bidder and target are negative in almost half of the acquisitions (Martynova and Renneboog, 2008, 2011). M\&A failure is often attributed, among other things, to lack of experience with the takeover process at the managerial, director, or firm level (Aktas et al., 2009; Cartwright and Schoenberg, 2006; Kim and Alvarez, 2019; Maas et al., 2019; McDonald et al., 2008; Zollo and Singh, 2004). Fifth, director human capital and, in particular, relevant acquisition experience is generally scarce (Castanias and Helfat, 1991; Khanna et al., 2014). And most importantly, $M \& A$ is one of the few strategic tasks in which both executive and non-executive are fully involved. This makes it the right context to examine the effect of task-specific human capital on the remuneration of both types of directors.

Against this background, we examine whether directors receive a pay premium for this important type of human capital, their acquisition experience, and identify the conditions under which acquisition experiences are compensated differently across and within firms. We use a rich dataset that covers all constituents of the FTSE All-Share Index, 2,243 unique firms, over a period of 17 years (1999-2016), merged with M\&A and ownership data from Thomson-Reuters, board of director data from BoardEx, and financial data from Datastream. First, our results reveal that directors receive a pay premium (total compensation) for their acquisition experience. Second that the relative size of this premium is higher for non-executive directors than for executives. Third, that the compensation is higher when the director was involved in successful acquisitions. Fourth, a director's acquisitions experience is more valuable (and priced) in firms with limited acquisition experience relative to firms with an abundance of acquisition experience. When we disaggregate the effect of acquisition experience to the different components of compensation, we find that experience is predominantly priced in the base salary (and not in the bonus or equity-based components of pay). In testing our hypotheses, we control for a broad set of managerial skills and experience that directors gained through working in different positions, firms, and industries. We also follow Brockman et al., (2016) and Custódio et al., (2013) to construct an experience index to control for generic and specific skills. In terms of model specification, we control for director-firm fixed effect to rule out time invariant director and firm level effects that may affect remuneration. We also verify the robustness of our results by using instrumental variables, and different measures of M\&A experience (such as industry-specific, international experience, experience on a target's board, etc.).

Our study contributes to the literature on remuneration and human capital in the following ways. First, the human capital literature focuses primarily on general managerial experience, measured by the number of years and of positions that directors have held within or across firms and industries without considering actual tasks they had performed (Brockman et al., 2016; Carpenter et al., 2001; Fedaseyeu et al., 2018). By examining whether task-specific human capital is contractually priced and providing evidence corroborating this claim, we bring new insights into how experience is captured at the granular level. The key strength of this granular conceptualization is its measurement validity. Second, the finding that the relative size of a takeover experience varies between non-executive and executive directors suggests that firms not only consider task-specific human capital in determining remuneration, but also weigh the expected effectiveness of this experience in a corporate context by the role a director plays in the firm. Third, the higher pay for acquisition experience based on past successful takeovers suggests that firms pay premiums conditional on directors' ability to accomplish a takeover task well and that past successes in handling takeovers signal future success. While learning from failed acquisitions is not excluded, firms appear to shy away from paying a premium for learning from failures. Fourth, the pay related to takeover experience depends on the acquisition experience already available in the firm. Firms without much collective acquisition experience recognize the importance of acquisition experience of directors by offering a higher remuneration. The above contingent factors shed new light on why firms might offer different pay premiums for directors with similar taskspecific human capital.

This study also contributes to the acquisition literature. Several studies examined acquisition experience either at the firm (e.g., Aktas et al., 2009), non-executive or executive director level (Field and Mkrtchyan, 2017; Harford and Schonlau, 2013; Mira et al., 2018). We extend this literature by providing some nuances in the interplay between acquisition experience at the individual and firm's level as well as the value of this experience for executive and non-executive directors in determining their remuneration. 


\section{Institutional background, theory, and hypotheses}

\subsection{Institutional background}

Remuneration disclosure of executive and non-executive directors is an important aspect of the UK corporate regulation. The law requires UK listed companies to prepare Directors' Remuneration Report as a separate section within the annual financial report (UK Companies Act, 2006, s. 422). It also gives extensive guidance on the composition of the executive director compensation such that it should be "designed to promote the long-term success of the company" (UK Corporate Governance Code - henceforth CGC - 2018, D.1), performance-related elements are supposed to be "transparent, stretching and rigorously applied" (UK CGC, 2018), D.1), and a formal and transparent remuneration policy is to be put in place (UK CGC, 2018, D.2).

For non-executive directors, the CGC states that their remuneration should reflect 'time commitment and responsibilities of the role' and should not consist of share options (UK CGC, 2016, D.1.3). More importantly, the code explicitly states that non-executive compensation can be determined by the board or the articles of association and offers discretion to companies to comply with this guideline or explain deviations (UK CGC, 2018). Consistent with these requirements, non-executive directors are not paid the same fee across the board, their pay varies with individual traits, predominantly age, tenure, and network size (Renneboog and Zhao, 2011; Goh and Gupta, 2016), gender, and director independence (Geiler and Renneboog, 2016).

In sum, the prescriptions of the CGC on non-executive director pay suggest that it is not only determined by the amount of time they spent on the board and the responsibilities they assume (e.g. committee memberships), but also by the experience they bring to the board. This is also in line with the international corporate governance guideline which explicitly states that non-executive directors' pay should reflect the director's contribution to the firm from experience, quality of input, and leadership (ICGN, 2010, 2.1).

With this in mind, we examine the pay premium that directors, both executive and non-executive, receive for their acquisition experiences and the contingent factors that ameliorate or weaken this relationship.

\subsection{Theory and hypotheses}

\subsubsection{Directors' acquisition experience and remuneration}

Human capital refers to the set of skills, knowledge, and experience that individuals accumulate through formal education, on-the-job training, and work experience (Becker, 1995; Coff and Kryscynski, 2011). The development of these skills and expertise requires investments of time, money and effort, in anticipation of a return in the form of higher pay and improved individual- and hence corporate performance.

In the corporate governance literature, human capital is primarily proxied by experience (e.g., Brockman et al., 2016; Carpenter et al., 2001; Fedaseyeu et al., 2018), with a few exceptions where it is measured by formal training (e.g. Datta and Iskandar-Datta, 2014). Experience is one type of human capital, developed by repeatedly performing a specific (coded) process and receiving performance feedback (Kolb and Kolb, 2005), and can be either task-specific or not. The former type is measured by the number of times directors perform a particular task, while the latter type is measured by the number of years a position (or positions) is (are) held by a director. In line with the definition of experience-based human capital, we conceptualize acquisition experience as being repeatedly engaged in takeovers, a task-specific experience. Repetition enables one to discern certain patterns in the action consequence loop and helps to develop a mental scheme that can be retrieved when similar environmental cues are faced (Ericsson and Lehmann, 1996; Hayward, 2002; Yeo and Marquardt, 2015). In the case of complex operations (such as takeovers), the number of repetitions necessary to identify patterns and draw valid inferences may be higher than for simpler tasks in which patterns are easily discernable (Hayward, 2002). Acquisitions are among the most publicly visible strategic actions; they require complex and far-reaching decisions that demand the attention and contribution of the entire board of directors (McNulty and Pettigrew, 1999).

Several studies point out the relevance of acquisition experience on acquisition performance in which they measure acquisition experience at the level of the firm (e.g., Aktas et al., 2011; Zollo and Singh, 2004), the board (Hayward, 2002; McDonald et al., 2008; Nadolska and Barkema, 2014) and the individual director (e.g. the CEO) (Field and Mkrtchyan, 2017). These studies indicate the positive effect of acquisition experience, at different levels of analysis, on the performance of acquisitions. They imply that with repeated acquisitions firms learn (develop certain routines) and directors gain expertise to handle acquisitions successfully.

This is also reflected in the labor market where acquisition experience can increase the subsequent board seats offered to CEOs (Harford and Schonlau, 2013) and non-executive directors (Mira et al., 2018). The implication is that acquisition experience is valuable human capital as it may improve future acquisition performance and such that companies recruit directors with acquisition experience to leverage on their expertise. Therefore, we argue that the value of this experience should not only be observed in the demand for new board positions as documented by the above studies but also in the remuneration a firm offers to directors with acquisition experience. So, we expect:

H1: The acquisition experience of executive directors and non-executive directors is priced in their remuneration contract. 


\subsubsection{Remuneration returns of director acquisition experience: Contingent factors}

After establishing the baseline relation between acquisition experience and remuneration, we argue that the above contractual relation may depend on three important factors, related to (i) a director's position, i.e, whether a director assumes an executive or non-executive role in the firm, (ii) whether his or her past acquisition experience was with successful or unsuccessful takeovers, which may signal his or her ability to undertake future successful acquisitions and, (iii) whether acquisition experience is scarcely or relatively abundantly present in the firm. We develop hypotheses on these three contingencies in the subsequent section.

\section{Director type}

The roles that executive and non-executive directors typically play in a company are complementary (Hambrick et al., 2015). While CEOs and other executive board members are responsible for managing the company on a day-to-day basis, non-executive directors are expected to provide them with advice on strategic issues and monitor their work on behalf of the shareholders (Hillman and Dalziel, 2003; Mira et al., 2018). The presumption that executives who are not monitored engage in suboptimal decision-making, warrants the presence of non-executive directors on the board and their engagement in strategic decisions of higher importance such as mergers and acquisitions (Fama, 1980). For non-executive directors to properly carry out their advisory and supervisory roles, they need to have the necessary knowledge and matching incentives (Zattoni and Cuomo, 2010).

Agency theory presumes that executive directors' appetite for acquisitions may not be completely aligned with the interests of shareholders and other stakeholders (Fama and Jensen, 1983). This is partly because acquisitions have two possible consequences for executive remuneration: a compensation increase due to acquisition performance or due to an increase in firm size following the acquisition. Girma et al. (2006) confirms the effect of these two on executive remuneration. Another study shows that firm size accounts for more than 45 percent of the variance in remuneration, whereas firms' overall performance merely explains 5 percent (Tosi et al., 2000). This implies that executive directors may be willing to undertake value-reducing acquisitions given the positive net effect of corporate size on their compensation (Harford and Li, 2007; Wright et al., 2002). Second, executive remuneration can go up (at least temporarily) due to a performance bonus paid out for acquiring another firm (regardless of its success) (Guest, 2009). In other words, acquisitions motivated by empirebuilding tendencies may still occur even when executive directors are experienced. In contrast, non-executive directors with relevant acquisition experience are bound to more easily spot deals that are motivated by executive directors' own interests and they may, therefore, constrain these executives' takeover transactions by requesting important target details, or information on the overall deal value (Armstrong et al., 2014; McNulty and Pettigrew, 1999). This is consistent with the study by Johnson, Hoskisson, and Hitt (1993), which shows that non-executive board members are more involved in strategic decisions when executives need expertise to craft strategies due to limited experience or a lack of incentives.

In sum, what the above arguments suggest is that the important role assigned to non-executive directors to curb valuedestroying acquisitions and hence to oppose executive directors' possibly ill-considered pro-takeover stance pleads for rewarding non-executive's corporate acquisition experience. Consequently, the acquisition experience of non-executive directors is likely to be valued proportionally more by firms and thus remunerated accordingly. Consequently, we hypothesize:

$\mathrm{H} 2$ : Acquisition experience is priced relatively more in non-executive director remuneration contracts than in executive director remuneration contracts

\subsection{Quality of acquisition experience}

Firms remunerate directors with acquisition experience under the premise that this expertise will be used to manage future acquisitions successfully (Harford and Schonlau, 2013; Mira et al., 2018). Experiential learning theory suggests that directors learn from undertaking acquisitions through repetition, getting feedback, and identifying patterns that can be replicated in similar settings (Hayward, 2002; Kolb and Kolb, 2005; Zollo and Singh, 2004). This may entail that, ceteris paribus, as the number of acquisitions in which directors engage increases, they are able to leverage on their expertise to successfully make future acquisitions (Greve, 2003; Kolb and Kolb, 2005). While being involved in acquisitions presents opportunities to learn, only those acquisitions followed by a better acquisition performance may count in the learning process. Successful acquisitions (that yield positive announcement returns) may hinge on directors' expertise on how to reapply past successful takeover processes (Nadolska and Barkema, 2014). Indeed, Field and Mkrtchyan (2017) show that directors' past successful acquisition experience has a strong positive impact on future performance. Hence, a track record of past acquisition success may justify higher remuneration as it increases the likelihood of undertaking successful future acquisitions and reduce significantly failing ones. Consequently, companies may prefer directors with such expertise and hence be willing to remunerate them better.

H3: Past acquisition experience is priced in directors' remuneration contracts provided that the experience is based on successful acquisitions. 


\subsection{Firms' acquisition experience}

Studies that explore the effect of acquisition experience on acquisition performance have measured experience at the level of the individual (Harford and Li, 2007), the team (Nadolska and Barkema, 2014; McDonald et al., 2008), and the firm (Zollo and Singh, 2004). This implies that acquisition experience, seen as knowledge, can reside at different levels in the firm (Ployhart et al., 2014) but, with exception of few articles (Crocker and Eckardt, 2014; Eckardt et al., 2018), little attention has been paid to how the presence of knowledge at the firm-level affects the value firms assign to knowledge residing at the individual level.

To realize corporate goals, individuals and teams need to perform many tasks supported by company guidelines and routines. In the context of acquisitions, companies that repeatedly engage in acquisitions tend to have a robust set of routines, coded or encoded procedures that directors refer to when they plan acquisitions (Zollo and Singh, 2004). In contrast, companies with limited acquisition experience have to explore, starting from scratch, and learn how to manage such major decisions and processes. If a firm has extensive acquisition experience owing, for example, to serial acquisitions in the past, an individual director's acquisition experience may add little to the already existing expertise within the firm (Collins et al., 2009; Hayward and Hambrick, 1997; Zollo and Singh, 2004). Thus, directors who plan a takeover in firms with developed routines, procedures, and guidelines can rely on them to make the takeover successful even though s/he has limited acquisition experience. In contrast, if the overall level of acquisition experience in the firm is low, a director's acquisition experience becomes relatively more valuable. Consequently, the value and hence the remuneration attributed to directors' acquisition experience may depend on the scarcity of acquisition experience at the firm level. We, therefore, advance the following hypothesis:

H4: A director's acquisition experience is only priced in her/his remuneration contract when the firm and/or the other board members have little acquisition experience.

\section{Sample, variables and methodology}

\subsection{Sample selection}

Our sample includes all listed firms on the London Stock Exchange that are constituents of the FTSE All-Share Index, which represent more than 98 percent of the market capitalization of all listed UK companies in any year. We merge data from three databases: (i) Thomson-Reuters Eikon, which contains acquisition information needed to calculate acquisition experience and comprehensive ownership information at the director and firm levels, (ii) BoardEx, which comprises the corresponding information on remuneration, governance, and director characteristics, and (iii) Datastream, which includes accounting and stock-price information (see Appendix 1 for variable definitions). Our final dataset covers 2,243 unique firms over a period of 17 years (1999-2016). Total remuneration for executive and non-executive directors has increased in most years since 1999 with exception of the period corresponding to the financial crisis in 2008-2009. In the final dataset, we have 29,146 director-firm-year observations, 2,288 executives (including CEOs), and 3,492 non-executive directors.

\subsection{Variable definition and statistics}

In Table 1, we categorize our main and control variables into eight panels. In panel A, our primary dependent variable is the total remuneration at the director-firm-year level. Total remuneration is the sum of base salary, bonus, and long-term incentive pay (Datta and Iskandar-Datta, 2014), each of which we also investigate in our empirical analysis. The annual mean (median) total compensation across all years amounts to $£ 1,140,217$ ( $£ 643,000$ ) for executives (including CEOs), and $£ 63,386$ $(£ 40,000)$ for non-executive directors. These figures tie in with earlier studies on executive and non-executive director compensation in the UK (Geiler and Renneboog, 2016; Renneboog and Zhao, 2011). The coefficient of variation (ratio of the standard deviation to the mean) for compensation of non-executives amounts to $20.13 \%$ and illustrates significant variability for non-executive directors. Contrary to common belief that non-executive directors serving on the same board are paid equally, we observe in our data that non-executive compensation does actually differ significantly and is determined by experience, capability, tenure, and roles (which is also reported by Goh and Gupta, 2016). Take Marks and Spencer Group Co., a leading retail company in the UK, for example. In 2014, its eight non-executive directors' compensation ranged from $£ 18,000$ to $£ 450,000$ (see Appendix 2 for more details) and, even after controlling for committee memberships, the large pay variation remains.

In panel B, we present the descriptive statistics of our independent variables. Director acquisition experience is measured as the sum of all announced acquisitions in which a director has been involved. It should be noted that while our sample on the relation between remuneration and director experience starts in 1999, we go back to 1978 to determine a director's acquisition experience (as our acquisition data start in this year). This experience measure is calculated at the individual level and across all directorships that this individual has held in his current and previous firms. That is, if a director has held positions in two companies and each company has conducted one acquisition in the past, the director's acquisition experience is two. We also propose alternative measures of acquisition experience: (i) the number of large acquisitions (acquisitions with a transaction value above the industry median), (ii) the number of completed acquisitions, and (iii) a combined 
Table 1

Descriptive statistics.

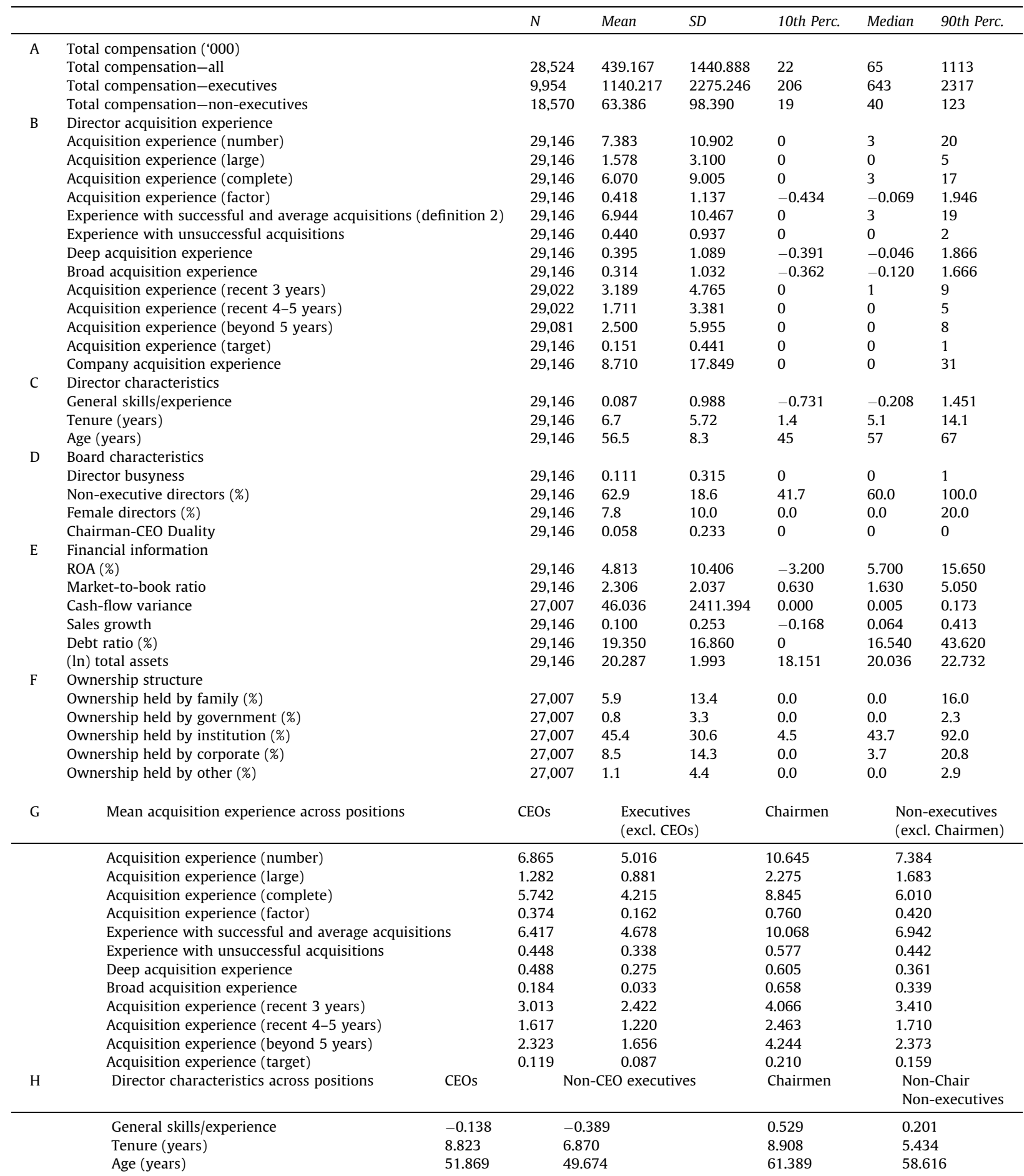

This table presents descriptive statistics of the main variables. Panel A reports statistics of dependent variables: director's total compensation, consisting of salary, bonus, equity-based compensation and other compensation. Panel B reports statistics of various acquisition experience measures. Control variables including director characteristics, board characteristics, financial information and ownership structure are summarized in Panel C to F. In Panel G and $\mathrm{H}$, we show acquisition experience statistics and director characteristics across director positions. Detailed variable definitions are given in Appendix 1. 
acquisition measure composed of three measures of acquisitions (number of acquisitions, of completed acquisitions, and of large acquisitions) obtained by means of factor analysis. We show in Panel B that directors experienced seven deals on average, six of which were completed and two of which were classified as large.

The second key independent variable is the quality of acquisition experience. We partition individual acquisition experiences based on cumulative abnormal returns (CARs) around the acquisition announcement into experience with successful, average, and unsuccessful acquisitions whereby successful (unsuccessful) acquisitions have a CAR of 0.5 standard deviations above (below) the mean CARs in the same industry and year ${ }^{2}$ and the remaining acquisitions are labelled as 'average' acquisitions. The CARs are calculated over a window of 3 days around the acquisition announcements. About 0.5 acquisitions per director are categorized as successful and a similar number can be classified as unsuccessful. As we will later find that experience with successful and average acquisitions have comparable effects on remuneration, we will combine them into one category in Panel B and the regression analyses below.

To capture acquisition experience heterogeneity, we use some alternative definitions. First, we define deep acquisition experience, whereby deep acquisitions include: (i) domestic acquisitions, (ii) focused acquisitions (bidder and target operate in the same industry), (iii) acquisitions by an acquirer with focused operations (the bidder is active in a single industry), or (iv) acquisition of a focused target (operates in a single industry). We expect that directors are more likely to obtain specialized and industry-specific knowledge through deep acquisitions. In order to aggregate the above characteristics, we conduct a factor analysis. Broad acquisition experience is based on involvement in international (cross-border) takeovers or diversified ones (whereby the target is either diversified or is operational in an industry other than the one of the bidder). A second set of definitions hinges on how much time has gone by since one has accumulated acquisition experience. More recent acquisition experience may obviously be more valuable. We examine the recency of the acquisition experience by focusing on involvement in acquisitions within the last three, last four to five years or beyond five-years. Third, we label 'target experience' as the experience gained by being involved in acquisitions as a director on the board of target firms. Finally, we also measure acquisition experience at the firm level, which is gathered by counting the number of acquisitions that a firm has carried out since the beginning of the sample period. The acquisition experience at the firm level has a wide variation with the mean (median) number of acquisitions being close to nine (zero) ${ }^{3}$.

In panels C, D, E \& F of Table 1, we present a set of control variables related to director and board characteristics, company financials, and ownership types. In line with the extant literature on the determinants of director remuneration, we control for the skills level of the CEO (general versus specialized) following the procedure Custódio et. al., (2013). We perform a factor analysis on the following director-level experiences: (i) number of past executive and non-executive board positions held by the director, (ii) number of firms s/he has worked for, (iii) number of industries that the firms s/he worked for were operating in, (iv) whether or not the director held a position as CEO in another firm, and (v) whether the director worked for a multi-division firm in the past. Different measures of experience have been used in the literature such as financial experience (Burak Güner et al., 2008), industry experience (Wang et al., 2015) and supply chain experience (Dass et al., 2014). Our experience index is quite comprehensive, in that it captures industry and functional experiences, as well as the broadness and depth of this experience. It controls for the effect of a wide range of director experience types not related to M\&A. Other director characteristic controls include director age and tenure on the board (Panel C). Governance characteristics, including the number of non-executive directors, percentage of non-executive directors, percentage of female directors and CEOchairman duality (Panel D), firm financial information including ROA, market-to-book ratio, cash-flow variance, sales growth, debt ratio (\% debt of total assets) and (ln)total assets (Panel E) and ownership structure (Panel F). Lastly, we discern acquisition experience and individual characteristics by board position (Panel $\mathrm{G}$ and $\mathrm{H}$ of Table 1). For instance, we document that chairmen and other non-executive directors tend to have more acquisition experience than CEOs and other executive directors. Moreover, chairmen and non-executive directors are older than CEOs and executive directors, which correlates with the fact that the former group has accumulated more experience. The definitions of all variables are summarized in Appendix 1 and the correlation matrix of all explanatory variables is provided in Table 2.

\subsection{Methodology}

Our baseline regression model in which we relate (executive and non-executive) director compensation to acquisition experience looks as follows:

Director_compensation $_{i, t}=\beta_{0}+\beta_{1}{ }^{*}$ Acquisition_experience $e_{i, t-1}+\beta_{2}{ }^{*}$ Director_traits $_{i, t-1}+\beta_{3}{ }^{*}$ Board_characteristics $_{i, t-1}+\beta_{4}{ }^{*}$ Financial_information ${ }_{i,-1}+\beta_{5}{ }^{*}$ Ownership_structure $i_{i,-1}+$ Time_fixed effects $_{t}+$ Director $^{*}$ Firm fixed effects ${ }_{i}+\varepsilon$

The main dependent variable is the director's $(\log )$ total compensation, while the main independent variable is the number of acquisitions a director was involved in. In addition, we consider a number of alternative acquisition experience measures to capture the heterogeneity in types of acquisition experience, e.g., the number of large and completed acquisitions and the number of acquisitions in recent years. The definitions of the various dependent, independent, and control variables are given in section 3.2 and Appendix A. We include director * firm fixed effects to exclude time-invariant individual director

\footnotetext{
${ }^{2}$ We also use alternative definitions of successful (unsuccessful) acquisition based on one and two standard deviations above (below) the industry average level. As shown in the results section, our results are robust across the three definitions.

${ }^{3}$ An alternative measure for firm-level acquisition experience is to take cumulative acquisition experience of all directors on board. Our findings remain unchanged with this alternative measure.
} 
Table 2

Correlation matrix.

\begin{tabular}{|c|c|c|c|c|c|c|c|c|c|c|c|c|c|c|c|c|c|c|c|c|c|}
\hline & & 1 & 2 & 3 & 4 & 5 & 6 & 7 & 8 & 9 & 10 & 11 & 12 & 13 & 14 & 15 & 16 & 17 & 18 & 19 & 20 \\
\hline 1 & (Log) total compensation & 1.00 & & & & & & & & & & & & & & & & & & & \\
\hline 2 & $\begin{array}{l}\text { Acquisition experience } \\
\text { (number) }\end{array}$ & 0.08 & 1.00 & & & & & & & & & & & & & & & & & & \\
\hline 3 & General skills/experience & -0.18 & 0.34 & 1.00 & & & & & & & & & & & & & & & & & \\
\hline 4 & Tenure & 0.14 & 0.11 & -0.12 & 1.00 & & & & & & & & & & & & & & & & \\
\hline 5 & Age & -0.37 & 0.19 & 0.11 & 0.25 & 1.00 & & & & & & & & & & & & & & & \\
\hline 6 & Director busyness & -0.19 & 0.16 & 0.58 & -0.06 & 0.11 & 1.00 & & & & & & & & & & & & & & \\
\hline 7 & Non-executive (\%) & -0.28 & -0.02 & 0.07 & -0.07 & 0.18 & 0.09 & 1.00 & & & & & & & & & & & & & \\
\hline 8 & Female (\%) & 0.02 & 0.04 & 0.02 & -0.07 & -0.03 & 0.00 & 0.15 & 1.00 & & & & & & & & & & & & \\
\hline 9 & CEO-Chairman Duality & 0.01 & -0.07 & -0.06 & 0.06 & 0.00 & -0.03 & -0.18 & -0.02 & 1.00 & & & & & & & & & & & \\
\hline 10 & ROA (\%) & 0.08 & 0.07 & -0.01 & 0.06 & 0.01 & -0.02 & -0.06 & 0.00 & 0.01 & 1.00 & & & & & & & & & & \\
\hline 11 & Market-to-book ratio & 0.12 & 0.06 & 0.00 & -0.05 & -0.06 & -0.03 & -0.18 & 0.03 & 0.02 & 0.21 & 1.00 & & & & & & & & & \\
\hline 12 & Cash-flow variance & 0.15 & 0.07 & -0.02 & 0.00 & 0.00 & -0.04 & -0.15 & 0.01 & 0.07 & 0.10 & 0.09 & 1.00 & & & & & & & & \\
\hline 13 & Sales growth & 0.00 & -0.01 & -0.02 & 0.02 & -0.01 & 0.00 & -0.02 & -0.02 & 0.00 & 0.08 & 0.02 & 0.01 & 1.00 & & & & & & & \\
\hline 14 & Ownership: family & 0.02 & -0.06 & -0.04 & 0.06 & -0.02 & -0.03 & -0.16 & -0.03 & 0.13 & 0.05 & 0.04 & 0.04 & 0.00 & 1.00 & & & & & & \\
\hline 15 & Ownership: government & 0.03 & 0.06 & 0.01 & -0.05 & 0.02 & 0.00 & 0.11 & 0.08 & -0.03 & -0.04 & -0.07 & 0.03 & -0.06 & -0.04 & 1.00 & & & & & \\
\hline 16 & Ownership: institution & 0.09 & 0.08 & 0.05 & -0.05 & 0.00 & 0.02 & 0.01 & 0.09 & -0.07 & 0.04 & 0.01 & 0.00 & -0.04 & 0.04 & 0.06 & 1.00 & & & & \\
\hline 17 & Ownership: corporate & 0.05 & 0.03 & -0.02 & 0.03 & 0.03 & -0.01 & -0.06 & -0.02 & 0.01 & 0.00 & 0.05 & 0.04 & 0.00 & 0.05 & -0.01 & 0.08 & 1.00 & & & \\
\hline 18 & Ownership: other & 0.01 & -0.02 & 0.00 & 0.00 & -0.01 & 0.00 & -0.03 & 0.01 & -0.03 & -0.01 & 0.02 & 0.00 & 0.01 & 0.02 & -0.02 & 0.00 & -0.04 & 1.00 & & \\
\hline 19 & Debt ratio (\%) & 0.10 & 0.11 & 0.03 & -0.05 & -0.03 & -0.02 & -0.07 & 0.02 & -0.01 & -0.03 & 0.00 & 0.04 & -0.09 & -0.02 & 0.04 & -0.05 & 0.04 & -0.05 & 1.00 & \\
\hline 20 & (Log) total assets & 0.23 & 0.30 & 0.03 & -0.11 & 0.08 & -0.03 & 0.16 & 0.20 & -0.09 & 0.09 & -0.02 & 0.27 & -0.07 & -0.13 & 0.23 & -0.01 & -0.06 & 0.01 & 0.32 & 1.00 \\
\hline
\end{tabular}

This table reports the correlations between the regression variables. 
characteristics which may depend on the firm that employs a director in a specific role and hence may drive remuneration. Thus, for an individual serving on two boards (e.g. as a CEO and as a non-executive director) we include two sets of fixed effects that capture the specific relation of the CEO with firm 1 and his non-executive role in firm 2 . This comprehensive set of fixed effects allows us to control for (i) time-invariant human capital such as ability and qualification (based on education); (ii) director characteristics that are firm dependent, and (iii) unobservable firm fixed effects. One potential issue with this approach is that cross director variation may be captured by the individual level fixed effects. As robustness checks, we use alternative fixed effects including firm and year fixed effects (Fedaseyeu et al., 2018) and firm*year fixed effect (Ferreira et al., 2020) to explore within-board variation. We obtain consistent results. We lag our independent and control variables to avoid problems related to simultaneity. Standard errors are clustered at company and director level, as the residuals of director remuneration are likely correlated both at the firm level and at the individual director level across firms.

Although we control for a broad set of control variables as well as director*firm and time fixed effects, there may still be an endogeneity issue induced by omitted factors that affect both compensation and remuneration. In order to address such potential endogeneity issues, we employ a variety of approaches including a 2SLS model in which we use, as an instrumental variable for director experience, a director's exposure to industrial acquisition active periods. Acquisition active periods are years with an abnormally high number of acquisitions in a given industry. During an acquisition active period (our instrument), directors are more likely to gain experience of acquisitions (our dependent variable), while there is no direct link with remuneration (our dependent variable). More details of this instrumental variable approach are provided below in section 4.2.1.

First stage:

Acquisition_experience $_{i, t-1}=\beta_{0}+\beta_{1}{ }^{*}$ Acquisition active periods $s_{i, t-1}+\beta_{2}{ }^{*}$ Director_traits $_{i, t-1}+\beta_{3}{ }^{*}$ Board_characteristics $_{i, t-1}+\beta_{4^{-}}$ ${ }^{*}$ Financial_information $_{i,-1}+\beta_{5}{ }^{*}$ Ownership_structure $_{i, t-1}+$ Time_fixed effects $_{t}+$ Director $^{*}$ Firm fixed effects $s_{i}+\varepsilon$

Second stage:

Director_compensation $_{i, t}=\beta_{0}+\beta_{1}{ }^{*}$ (Fitted) acquisition_experience $i_{i,-1}+\beta_{2}{ }^{*}$ Director_characteristics $_{i, t-1}+\beta_{3}{ }^{*}$ Board_characteristics $_{i, t-1}+$ $\beta_{4}{ }^{*}$ Financial_information $_{i, t-1}+\beta_{5}{ }^{*}$ Ownership_structure $e_{i, t-1}+$ Time_fixed effects $_{t}+$ Director $^{*}$ Firm fixed effects ${ }_{i}+\varepsilon$

\section{Empirical analysis}

\subsection{Results}

\subsubsection{Acquisition experience, director type, and remuneration}

To test the first two hypotheses, we perform a company-specific director fixed-effect regression of directors' compensation on acquisition experience (Table 3). We include generalist managerial skills (Custódio et al., 2013) as well as other director traits such as tenure and age. Table 3 shows that, in line with Hypothesis 1, total compensation of all directors, and for executive and non-executive directors specifically, is positively and significantly associated with acquisition experience (models (1), (2) and (3), respectively). The results are also economically important: a one standard deviation increase in acquisition experience among executives and non-executives is associated with increases in total compensation of 4.7 and 7.8 percent, respectively equivalent to $£ 53,266$ and $£ 4,957$ a year. Model (4) shows that the strength of the relations between acquisition experience and compensation is higher for non-executive directors than for executives. This finding fails to reject Hypothesis 2 as the acquisition experience of non-executive directors is rewarded proportionally more than that of executive directors. We further examine the acquisition experience obtained by top managerial positions (CEO, CFO) and the chairman in Models (5)-(7). Both the CEO and the chairman are financially rewarded for their acquisition experience, but this is not the case for the CFO. We focus on the base salary in Models (8) and (9) and find that salary is significantly and positively associated with acquisition experience. However, there is no such significant relationship between bonus or equitybased pay and acquisition experience (not tabulated). The non-significant relation for the bonus is not unexpected as a bonus is usually awarded if (accounting) performance benchmarks in the recent past (usually over the past financial year) were reached. So, it seems that acquisition experience is priced in the total remuneration package and more specifically through the base salary. We conclude that the first two hypotheses are supported as directors' expertise is factored in at the level of the fixed salary (and not at the level of bonuses and other incentive pay).

In relation to the control variables included in table 3, we observe that general skills/experience (in contrast to specialized skills such as those gained by a CFO, COO, marketing director, etc.) are priced more in remuneration contracts, which is in line with earlier findings in the literature. Tenure in the firm is financially rewarded (but not age - note that the correlation between age and tenure is not strong in Table 2). Director busyness and board characteristics do not consistently affect remuneration. Unsurprisingly, we also find positive relations between remuneration on the one hand and financial performance, sales growth, and firm size on the other. In all models above, we include firm specific director fixed effects and time fixed effects. These fixed effects enable us to focus on the relationship between individual acquisition experience and remuneration. We performed several robustness tests. First, we include only firm and time fixed effects (Fedaseyeu et al., 2018) to examine the remuneration variation across directors ${ }^{4}$. We find that in the full sample as well as in the executive and non-

\footnotetext{
${ }^{4}$ Given the large pay gap between executive and non-executive directors, we include a dummy variable to indicate that a director is an executive in the full sample regression.
} 
Table 3

Acquisition experience and compensation.

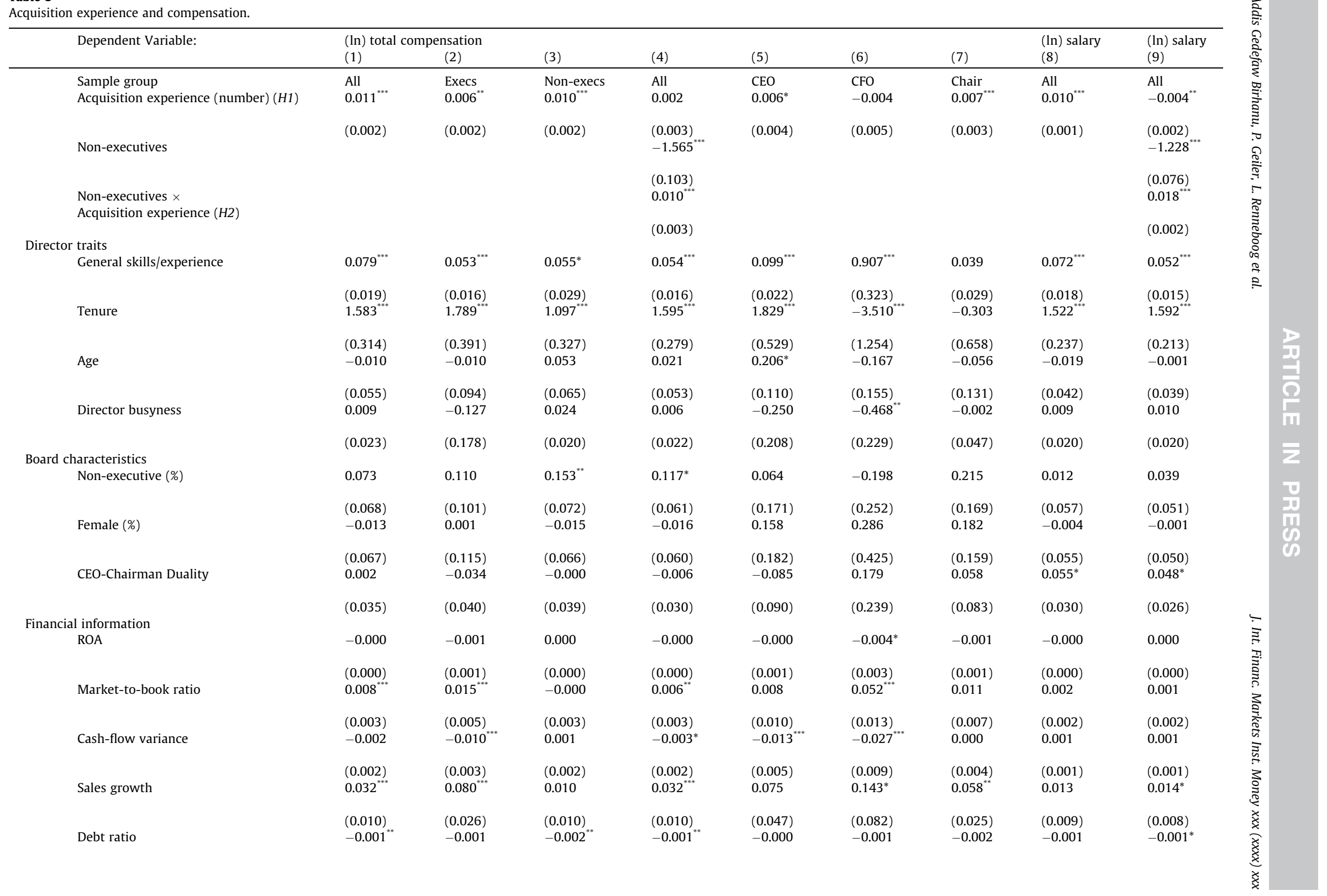


Table 3 (continued)

\begin{tabular}{|c|c|c|c|c|c|c|c|c|c|}
\hline Dependent Variable: & \multicolumn{7}{|c|}{ (In) total compensation } & $\begin{array}{l}\text { (In) salary } \\
(8)\end{array}$ & $\begin{array}{l}\text { (In) salary } \\
(9)\end{array}$ \\
\hline (Log) total assets & $\begin{array}{l}(0.001) \\
0.035^{* *}\end{array}$ & $\begin{array}{l}(0.001) \\
0.047^{* *}\end{array}$ & $\begin{array}{l}(0.001) \\
0.027^{* *}\end{array}$ & $\begin{array}{l}(0.001) \\
0.033^{* * *}\end{array}$ & $\begin{array}{l}(0.002) \\
0.060\end{array}$ & $\begin{array}{l}(0.004) \\
0.036\end{array}$ & $\begin{array}{l}(0.001) \\
0.096^{*+*}\end{array}$ & $\begin{array}{l}(0.000) \\
0.035^{* * *}\end{array}$ & $\begin{array}{l}(0.000) \\
0.037^{* * *}\end{array}$ \\
\hline \multicolumn{10}{|l|}{ Ownership structure } \\
\hline Ownership: family & $-0.085^{* * *}$ & -0.064 & $-0.073^{*}$ & $-0.078^{* * *}$ & -0.003 & -0.102 & -0.076 & $-0.063^{* *}$ & $-0.059^{* *}$ \\
\hline Ownership: government & $\begin{array}{l}(0.032) \\
0.026\end{array}$ & $\begin{array}{l}(0.046) \\
-0.623^{* *}\end{array}$ & $\begin{array}{l}(0.040) \\
0.452^{* * *}\end{array}$ & $\begin{array}{l}(0.030) \\
0.128\end{array}$ & $\begin{array}{l}(0.089) \\
-0.089\end{array}$ & $\begin{array}{l}(0.318) \\
-1.853^{* * *}\end{array}$ & $\begin{array}{l}(0.081) \\
0.314\end{array}$ & $\begin{array}{l}(0.026) \\
0.221\end{array}$ & $\begin{array}{l}(0.024) \\
0.296^{* *}\end{array}$ \\
\hline Ownership: institution & $\begin{array}{l}(0.199) \\
0.042^{* *}\end{array}$ & $\begin{array}{l}(0.299) \\
0.081^{* *}\end{array}$ & $\begin{array}{l}(0.157) \\
0.027\end{array}$ & $\begin{array}{l}(0.160) \\
0.057^{* * *}\end{array}$ & $\begin{array}{l}(0.552) \\
0.034\end{array}$ & $\begin{array}{l}(0.572) \\
0.025\end{array}$ & $\begin{array}{l}(0.304) \\
-0.028\end{array}$ & $\begin{array}{l}(0.151) \\
0.023\end{array}$ & $\begin{array}{l}(0.123) \\
0.034^{* *}\end{array}$ \\
\hline Ownership: corporate & $\begin{array}{l}(0.020) \\
0.059\end{array}$ & $\begin{array}{l}(0.032) \\
0.180^{* * * *}\end{array}$ & $\begin{array}{l}(0.020) \\
-0.046\end{array}$ & $\begin{array}{l}(0.018) \\
0.062^{*}\end{array}$ & $\begin{array}{l}(0.063) \\
0.248\end{array}$ & $\begin{array}{l}(0.109) \\
0.198\end{array}$ & $\begin{array}{l}(0.044) \\
0.020\end{array}$ & $\begin{array}{l}(0.016) \\
-0.008\end{array}$ & $\begin{array}{l}(0.015) \\
-0.005\end{array}$ \\
\hline Ownership: other & $\begin{array}{l}(0.042) \\
0.054\end{array}$ & $\begin{array}{l}(0.069) \\
0.284\end{array}$ & $\begin{array}{l}(0.033) \\
-0.015\end{array}$ & $\begin{array}{l}(0.035) \\
0.062\end{array}$ & $\begin{array}{l}(0.152) \\
0.320\end{array}$ & $\begin{array}{l}(0.141) \\
0.383\end{array}$ & $\begin{array}{l}(0.097) \\
0.079\end{array}$ & $\begin{array}{l}(0.031) \\
0.047\end{array}$ & $\begin{array}{l}(0.028) \\
0.058\end{array}$ \\
\hline Constant & $\begin{array}{l}(0.079) \\
3.775\end{array}$ & $\begin{array}{l}(0.199) \\
5.930\end{array}$ & $\begin{array}{l}(0.069) \\
-0.809\end{array}$ & $\begin{array}{l}(0.076) \\
3.201\end{array}$ & $\begin{array}{l}(0.309) \\
-7.148\end{array}$ & $\begin{array}{l}(0.387) \\
5.670\end{array}$ & $\begin{array}{l}(0.114) \\
6.174\end{array}$ & $\begin{array}{l}(0.065) \\
4.173\end{array}$ & $\begin{array}{l}(0.062) \\
4.023^{*}\end{array}$ \\
\hline & (3.386) & $(5.273)$ & $(4.106)$ & (3.225) & (6.179) & $(8.223)$ & $(8.668)$ & $(2.581)$ & $(2.398)$ \\
\hline Director * firm FE & Yes & Yes & Yes & Yes & Yes & Yes & Yes & Yes & Yes \\
\hline Year FE & Yes & Yes & Yes & Yes & Yes & Yes & Yes & Yes & Yes \\
\hline$R^{2}$ & 0.174 & 0.156 & 0.256 & 0.246 & 0.179 & 0.247 & 0.101 & 0.246 & 0.314 \\
\hline$N$ & 28,522 & 9953 & 18,569 & 28,522 & 3332 & 692 & 4753 & 28,479 & 28,479 \\
\hline
\end{tabular}

This table presents the regressions explaining directors' (natural logarithm) total compensation (models (1)-(7)) and (ln) base salary (models (8) and (9)) by acquisition experience and a set of control variables.

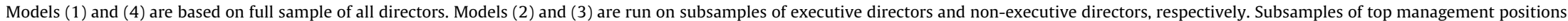

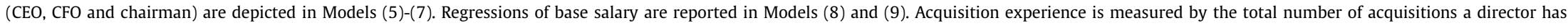

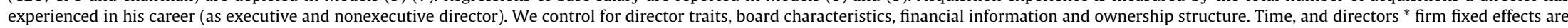

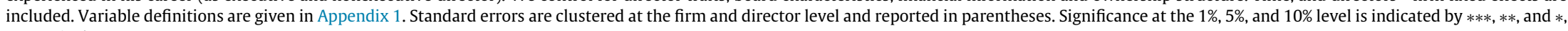
respectively. 
The quality of acquisition experience.

\begin{tabular}{|c|c|c|c|c|c|c|c|c|c|}
\hline & $\begin{array}{l}\text { Acquisition } \\
\text { Quality: } \\
\text { Definition } 1\end{array}$ & $\begin{array}{l}\text { Acquisition } \\
\text { Quality: } \\
\text { Definition } 2\end{array}$ & $\begin{array}{l}\text { Acquisition } \\
\text { Quality: } \\
\text { Definition } 3\end{array}$ & & & & & & \\
\hline & $(1)$ & (2) & (3) & $(4)$ & (5) & (6) & (7) & $(8)$ & (9) \\
\hline Sample group & All & Execs & Non-execs & All & Execs & $\begin{array}{l}\text { Non- } \\
\text { execs }\end{array}$ & All & Execs & $\begin{array}{l}\text { Non- } \\
\text { execs }\end{array}$ \\
\hline $\begin{array}{l}\text { Experience with successful } \\
\text { and average acquisitions }\end{array}$ & $0.008^{* * *}$ & -0.001 & $0.009^{* * *}$ & $0.008^{* * *}$ & 0.002 & $0.008^{* * *}$ & $0.008^{* * *}$ & 0.003 & $0.008^{* * *}$ \\
\hline$(H 3)$ & $(0.002)$ & $(0.004)$ & $(0.002)$ & $(0.001)$ & $(0.003)$ & $(0.002)$ & $(0.001)$ & $(0.003)$ & $(0.001)$ \\
\hline \multirow[t]{2}{*}{$\begin{array}{l}\text { Experience with unsuccessful } \\
\text { acquisitions }\end{array}$} & 0.010 & 0.008 & -0.001 & 0.016 & 0.020 & 0.002 & 0.022 & 0.004 & -0.008 \\
\hline & $(0.006)$ & $(0.011)$ & $(0.007)$ & $(0.012)$ & $(0.018)$ & $(0.013)$ & $(0.030)$ & $(0.033)$ & $(0.026)$ \\
\hline Director traits & Yes & Yes & Yes & Yes & Yes & Yes & Yes & Yes & Yes \\
\hline Board characteristics & Yes & Yes & Yes & Yes & Yes & Yes & Yes & Yes & Yes \\
\hline Financial information & Yes & Yes & Yes & Yes & Yes & Yes & Yes & Yes & Yes \\
\hline Ownership structure & Yes & Yes & Yes & Yes & Yes & Yes & Yes & Yes & Yes \\
\hline \multirow[t]{2}{*}{ Constant } & 3.820 & 6.133 & -0.794 & 3.790 & 5.944 & -0.769 & 3.775 & 6.018 & -0.775 \\
\hline & $(3.390)$ & $(5.275)$ & $(4.112)$ & (3.385) & $(5.301)$ & $(4.115)$ & $(3.390)$ & $(5.285)$ & $(4.112)$ \\
\hline Director * firm FE & Yes & Yes & Yes & Yes & Yes & Yes & Yes & Yes & Yes \\
\hline Year FE & Yes & Yes & Yes & Yes & Yes & Yes & Yes & Yes & Yes \\
\hline$R^{2}$ & 0.173 & 0.156 & 0.255 & 0.173 & 0.156 & 0.255 & 0.173 & 0.156 & 0.255 \\
\hline$N$ & 28,522 & 9953 & 18,569 & 28,522 & 9953 & 18,569 & 28,522 & 9953 & 18,569 \\
\hline
\end{tabular}

This table presents the regressions explaining directors' (ln) total compensation by quality of acquisition experience. The full sample is used in model (1). Models (2) and (3) are run on subsamples of executive and nonexecutive directors respectively. Each model in model (1) - (3) includes two measures of acquisition quality: experience with successful and average acquisitions, and unsuccessful acquisitions experience (no acquisition experience is the left out benchmark). Definition 1 for acquisition quality is as follows: successful acquisitions have a CAR[0,1] higher than the average market reaction plus 0.5 standard deviation; unsuccessful ones have a CAR[0,1] lower than the average market reaction minus 0.5 standard deviation; and the other acquisitions are labelled 'average acquisitions. Estimates based on definitions 2 ( 1 standard deviation from the average market reaction) and 3 ( 2 standard deviations from the average market reaction) are reported in models (4)-(6) and models (7)-(9) respectively. We control for director characteristics, board characteristics, financial information and ownership structure, as in Table 3. Time and director * firm fixed effects are included. Detailed variable definitions are given in Appendix 1. Standard errors are clustered at the firm-director level and reported in parentheses. Significance at the $1 \%, 5 \%$, and $10 \%$ level is indicated by $* * *$, $* *$, and $*$, respectively.

executive subsamples, acquisition experience significantly increases total compensation. In a second robustness check, we include firm* ${ }^{*}$ ear fixed effects (Ferreira et al., 2020). While we omit some control variables to avoid multi-collinearity, acquisition experience remains significantly and positively correlated with total compensation. Therefore, the difference in acquisition experience explains remuneration variation across directors on the same board. Our results are robust in alternative fixedeffects settings.

\subsubsection{Quality and scarcity of acquisition experience and remuneration}

We turn to the effect of a director's past track record in terms of the quality of the acquisitions, namely his involvement in successful acquisitions. In Table 4, we find that acquisition experience with successful and average acquisitions is financially rewarded for all directors (model (1)), and this relation is driven by the subsample of non-executive directors (model (3)). Exposure to unsuccessful past acquisitions is not priced in the remuneration contract - so experience with poor acquisitions does not seem to be considered as a learning opportunity as it has no impact (relative to no prior acquisition experience, the benchmark). The effect of experience with successful and average acquisitions is economically important: a one standard deviation increase in such acquisition experience is associated with an increase in total compensation by 9.7 percent. Consequently, we cannot reject Hypothesis 3. We also use two other definitions of acquisition success/lack of success based on one or two standard deviations above/below the mean CAR. Models (4)-(9) yield similar results as for the base case models (1)-(3).

In sum, our results are consistent with the idea that a compensation premium exists only for experience with nonunsuccessful acquisitions or, in other words, for not having been involved in poor acquisitions. This implies that when a director has experience with poor acquisitions, the opportunity to draw lessons for what has gone wrong is not priced in the remuneration contract.

In Table 5, we examine whether the part of the remuneration explained by directors' acquisition experience depends on the extent to which a firm already embeds acquisition experience. We document that experience is valued by the firm, but the interaction term (acquisition experience $\times$ firm's acquisition experience) indicates that this is less so when the firm is a veteran on the acquisition market (Models (1)-(3)). In a subsequent step, we create a measure capturing relative experience as the number of acquisitions a director has been involved in minus the number of acquisitions the firm has initiated. In Model (4), we show that this relative experience is significantly and positively associated with director's compensation: a director is paid more if his acquisition experience exceeds that of the company (in other words, has been obtained externally). Lastly, we conduct subsample analyses in Models (5) and (6) for companies with and without acquisition experience. 
Table 5

The substitution effect of firm's collective acquisition experience.

\begin{tabular}{|c|c|c|c|c|c|c|}
\hline Dep. Var.: (In) total compensation & $(1)$ & (2) & (3) & (4) & (5) & $(6)$ \\
\hline Sample group & All & Execs & $\begin{array}{l}\text { Non- } \\
\text { execs }\end{array}$ & All & $\begin{array}{l}\text { All directors in firms without } \\
\text { acquisition experience }\end{array}$ & $\begin{array}{l}\text { All directors in firms with } \\
\text { acquisition experience }\end{array}$ \\
\hline \multirow[t]{2}{*}{ Acquisition experience (number) } & $0.013^{* * *}$ & $0.006^{* *}$ & $0.012^{* * *}$ & & $0.017^{* * *}$ & $0.006^{* * *}$ \\
\hline & $(0.002)$ & $(0.003)$ & $(0.002)$ & & $(0.003)$ & $(0.002)$ \\
\hline \multirow[t]{2}{*}{ Firm's acquisition experience } & $0.002^{* * *}$ & $0.003^{* * *}$ & $0.001^{*}$ & & & \\
\hline & $(0.000)$ & $(0.001)$ & $(0.000)$ & & & \\
\hline \multirow[t]{2}{*}{$\begin{array}{l}\text { Acquisition experience } \times \text { firm's } \\
\text { acquisition experience }(\mathrm{H} 4)\end{array}$} & $-0.001^{* * *}$ & -0.000 & $-0.001^{* * *}$ & & & \\
\hline & $(0.000)$ & $(0.000)$ & $(0.000)$ & & & \\
\hline \multirow[t]{2}{*}{ Relative acquisition experience } & & & & $0.025^{* * *}$ & & \\
\hline & & & & $(0.009)$ & & \\
\hline Director traits & Yes & Yes & Yes & Yes & Yes & Yes \\
\hline Board characteristics & Yes & Yes & Yes & Yes & Yes & Yes \\
\hline Financial information & Yes & Yes & Yes & Yes & Yes & Yes \\
\hline Ownership structure & Yes & Yes & Yes & Yes & Yes & Yes \\
\hline \multirow[t]{2}{*}{ Constant } & 3.848 & 6.279 & -0.799 & 4.446 & 3.133 & 7.241 \\
\hline & $(3.381)$ & $(5.247)$ & $(4.096)$ & $(3.547)$ & $(4.124)$ & $(5.336)$ \\
\hline Director * firm FE & Yes & Yes & Yes & Yes & Yes & Yes \\
\hline Year FE & Yes & Yes & Yes & Yes & Yes & Yes \\
\hline$R^{2}$ & 0.175 & 0.159 & 0.257 & 0.166 & 0.146 & 0.246 \\
\hline$N$ & 28,522 & 9953 & 18,569 & 27,054 & 18,319 & 10,203 \\
\hline
\end{tabular}

This table presents the regressions explaining directors' ( $\mathrm{ln}$ ) total compensation by acquisition experience measures and a set of control variables. A firm's acquisition experience is measured by the number of acquisitions it has made. The full sample is used in model (1). Models (2) and (3) are based on subsamples of executive and nonexecutive directors respectively. Relative acquisition experience, measured by director's acquisition experience minus firm's acquisition experience, replaces acquisition experience in model (4). Models (5) and (6) are based on subsamples of directors hired by firms without acquisition experience and directors hired by in firms with acquisition experience, respectively. We control for director traits, board characteristics, financial information and ownership structure. Time, and director * firm fixed effects are included. Variable definitions are given in Appendix 1 . Standard errors are clustered at the firm-director level and reported in parentheses. Significance at the $1 \%, 5 \%$, and $10 \%$ level is indicated by $* * *, * *$, and $*$, respectively.

The corresponding coefficients ( 0.017 and 0.006$)$ indicate that a director's acquisition experience is valued by both types of companies but almost three times more by firms without prior takeover experience. This set of results suggests that acquisition experience residing in the firm reduces the remuneration that directors receive as compensation for acquisition experience. ${ }^{5}$ In other words, companies reward director's expertise that is missing in a firm's repertoire.

In sum, our results suggest that acquisition experience is rewarded, depending on the position that directors assume in the firm, on directors' involvement in successful past acquisitions, and on the acquisition experience embedded in the firm.

\subsection{Robustness analyses}

\subsubsection{Endogeneity}

Acquisition decisions may not be exogenous and may be correlated with omitted, and possibly latent, variables that simultaneously drive total remuneration. Using lagged independent and control variables, as well as the various fixed effects mitigates but may not fully address endogeneity concerns. Therefore, we perform additional analyses to reduce such concerns.

A variable that could affect remuneration is a director's general reputational capital (Bugeja et al., 2009; Vafeas, 1999), which can be proxied by outside directorships that he or she is offered. A director who serves on the board of another firm may benefit from that firm's reputation and hence receive a higher remuneration. This would be even more so if the other firm is larger than the focal firm. Furthermore, serving on the board of a larger firm may also expose him to more acquisitions. Consequently, director's remuneration in a focal firm could be related to reputation arising from working in a large other (non-focal) firm and from the acquisition experience (that s/he obtained through that firm). To rule out director reputation effects derived from her/his current and past employment at another firm, we first calculate the sum of the size of all non-focal firms in which a director works or has worked over the previous year, and then divide it by the focal firm's size. So, we use the relative importance of his connections with other firms in terms of size as a proxy for reputation; in other words, directorships in other firms thus receive a higher weight based on corporate size of the other firm relative the size of the focal

\footnotetext{
${ }^{5}$ We also consider the timeliness of a firm's acquisition experience by retesting the models of Models (1), (5) and (6) of Table 5 and constraining the firm's past acquisition experience for the most recent three (five) years. We confirm that the results presented in Table 5 are upheld and hence that firm experience in recent years has a substitution effect (and not a complementary effect).
} 
Table 6

Analysis of reputational effects.

\begin{tabular}{|c|c|c|c|c|c|c|c|c|c|c|}
\hline Dep. Variable: $(\ln )$ total compensation & $(1)$ & $(2)$ & (3) & $(4)$ & (5) & (6) & (7) & $(8)$ & $(9)$ & $(10)$ \\
\hline Sample group: & All & Execs & $\begin{array}{l}\text { Non- } \\
\text { execs }\end{array}$ & All & All & Execs & $\begin{array}{l}\text { Non- } \\
\text { execs }\end{array}$ & All & Execs & $\begin{array}{l}\text { Non- } \\
\text { execs }\end{array}$ \\
\hline Acquisition experience (number) (H1) & $0.008^{* * * *}$ & $0.005^{* *}$ & $0.006^{* * *}$ & 0.002 & & & & $0.010^{* * *}$ & $0.006^{* *}$ & $0.008^{* * *}$ \\
\hline & $(0.001)$ & $(0.002)$ & $(0.002)$ & $(0.003)$ & & & & $(0.002)$ & $(0.003)$ & $(0.002)$ \\
\hline Director general reputation & $0.117^{* * *}$ & 0.021 & $0.132^{* * *}$ & $0.117^{* * * *}$ & $0.118^{* * *}$ & 0.023 & $0.134^{* * *}$ & $0.116^{* * *}$ & 0.021 & $0.131^{* * *}$ \\
\hline Non-executives & $(0.011)$ & $(0.038)$ & $(0.010)$ & $\begin{array}{l}(0.010)^{* * *} \\
-1.528^{* *}\end{array}$ & $(0.011)$ & $(0.039)$ & $(0.010)$ & $(0.011)$ & $(0.038)$ & $(0.010)$ \\
\hline $\begin{array}{l}\text { Non-executives } \times \\
\text { Acquisition experience }(\mathrm{H} 2)\end{array}$ & & & & $\begin{array}{l}(0.102) \\
0.007^{* *} \\
(0.003)\end{array}$ & & & & & & \\
\hline $\begin{array}{l}\text { Experience with successful and average } \\
\text { acquisitions (H3) }\end{array}$ & & & & & $\begin{array}{l}0.006^{* * *} \\
(0.001)\end{array}$ & $\begin{array}{l}0.002 \\
(0.003)\end{array}$ & $\begin{array}{l}0.006^{* * *} \\
(0.001)\end{array}$ & & & \\
\hline $\begin{array}{l}\text { Experience with unsuccessful } \\
\text { acquisitions }\end{array}$ & & & & & $\begin{array}{l}0.012 \\
(0.012)\end{array}$ & $\begin{array}{l}0.021 \\
(0.018)\end{array}$ & $\begin{array}{l}-0.002 \\
(0.012)\end{array}$ & & & \\
\hline Firms' acquisition experience & & & & & & & & $0.002^{* * *}$ & $0.003^{* * *}$ & $0.001^{* *}$ \\
\hline $\begin{array}{l}\text { Directors' acquisition experience } \times \text { firms' } \\
\text { acquisition experience }(\mathrm{H} 4)\end{array}$ & & & & & & & & $\begin{array}{l}(0.000) \\
-0.001^{* * *} \\
(0.000)\end{array}$ & $\begin{array}{l}(0.001) \\
-0.001 \\
(0.000)\end{array}$ & $\begin{array}{l}(0.001) \\
-0.001^{* * *} \\
(0.000)\end{array}$ \\
\hline Director traits & Yes & Yes & Yes & Yes & Yes & Yes & Yes & Yes & Yes & Yes \\
\hline Board characteristics & Yes & Yes & Yes & Yes & Yes & Yes & Yes & Yes & Yes & Yes \\
\hline Financial information & Yes & Yes & Yes & Yes & Yes & Yes & Yes & Yes & Yes & Yes \\
\hline Ownership structure & Yes & Yes & Yes & Yes & Yes & Yes & Yes & Yes & Yes & Yes \\
\hline Constant & $\begin{array}{l}3.968 \\
(3.582)\end{array}$ & $\begin{array}{l}7.158 \\
(5.827)\end{array}$ & $\begin{array}{l}-1.497 \\
(4.180)\end{array}$ & $\begin{array}{l}3.317 \\
(3.397)\end{array}$ & $\begin{array}{l}3.961 \\
(3.583)\end{array}$ & $\begin{array}{l}7.171 \\
(5.860)\end{array}$ & $\begin{array}{l}-1.483 \\
(4.188)\end{array}$ & $\begin{array}{l}4.030 \\
(3.580)\end{array}$ & $\begin{array}{l}7.500 \\
(5.798)\end{array}$ & $\begin{array}{l}-1.490 \\
(4.171)\end{array}$ \\
\hline Director * firm FE & Yes & Yes & Yes & Yes & Yes & Yes & Yes & Yes & Yes & Yes \\
\hline Year FE & Yes & Yes & Yes & Yes & Yes & Yes & Yes & Yes & Yes & Yes \\
\hline$R^{2}$ & 0.182 & 0.157 & 0.284 & 0.258 & 0.181 & 0.156 & 0.284 & 0.182 & 0.159 & 0.285 \\
\hline$N$ & 28,080 & 9839 & 18,241 & 28,080 & 28,080 & 9839 & 18,241 & 28,080 & 9839 & 18,241 \\
\hline
\end{tabular}

This table shows the regression results explaining directors' (In) total compensation by acquisition experience measures and a set of control variables. To proxy for a director's reputation, we use his directorships at firms other than the focal firm: we first calculate the sum of the size of all non-focal firms in which a director works or has worked over the previous year, and then divide it by the focal firm's size, which yields the relative importance of his connections with other firms in terms of size. The table retest the models presented in Tables 1-3 while controlling for director general reputation. We control for director traits, board characteristics, financial information and ownership structure. Time, and director * firm fixed effects are included. Variable definitions are given in Appendix 1. Standard errors are clustered at the firm-director level and reported in parentheses. Significance at the 1\%, $5 \%$, and $10 \%$ level is indicated by $* * *, * *$, and $*$, respectively.

firm. In Table 6, we retest our hypotheses by including director general reputation as an additional explanatory variable. The coefficients of reputation are highly statistically significant, indicating that this type of reputation is indeed associated with higher total remuneration for both executive and non-executives, and hence all directors. More importantly, acquisition experience remains significantly and positively related to remuneration, suggesting that directors are rewarded for acquisition experience on top of a reputation premium (Models (1)-(3)). It should be noted that the effect is greater for nonexecutive directors (as the interaction term non-executives $\times$ acquisition experience in Model (4) is positive and significant). This means that we can confirm our earlier findings related to Hypotheses 1 and 2 . We continue by verifying, while controlling for director general reputation, the results pertaining to the idea that experience with unsuccessful acquisitions is not financially rewarded and find that this is mainly the case for non-executive directors as reported above (Models (5)-(7)). We also confirm that while controlling for a director's general reputation, both types of directors receive a higher remuneration when they have more acquisition experience and that the impact of acquisition experience on remuneration of nonexecutive directors goes down when the firm itself has accumulated acquisition experience (Models (8)-(10)). ${ }^{6}$

To address other endogeneity concerns, we use industry-specific acquisition activity as an instrumental variable for a director's acquisition experience in Table 7. The idea is that industry-specific acquisition activities, e.g., a consolidating merger wave, increase the number of acquisitions to which a director is exposed to, but will otherwise not affect director remuneration directly or through any unobservable director characteristic. It is possible that directors received a bonus

\footnotetext{
${ }^{6}$ We also employ another measure of reputation by comparing the level of performance (the most recently available ROA) of the other firm(s) in which directors work. We find that all results on a director's acquisition experience are upheld (not tabulated).
} 
Table 7

Exposure to acquisition active periods (Instrumental Variable approach).

\begin{tabular}{|c|c|c|c|c|c|c|c|c|c|c|}
\hline $\begin{array}{l}\text { Second stage regression } \\
\text { Dep. Variable: }(\ln ) \text { total compensation }\end{array}$ & $(1)$ & $(2)$ & (3) & $(4)$ & $(5)$ & $(6)$ & $(7)$ & $(8)$ & (9) & $(10)$ \\
\hline Sample group: & All & Execs & $\begin{array}{l}\text { Non- } \\
\text { execs }\end{array}$ & All & All & Execs & $\begin{array}{l}\text { Non- } \\
\text { execs }\end{array}$ & All & Execs & $\begin{array}{l}\text { Non- } \\
\text { execs }\end{array}$ \\
\hline Acquisition experience (number) (H1) & $0.023^{* * *}$ & 0.030 & $0.017^{* *}$ & 0.012 & & & & $0.025^{* * *}$ & 0.040 & $0.018^{* *}$ \\
\hline & $(0.008)$ & $(0.025)$ & $(0.007)$ & $(0.011)$ & & & & $(0.009)$ & $(0.036)$ & $(0.008)$ \\
\hline Director general reputation & $0.104^{* * * *}$ & -0.005 & $0.124^{* * *}$ & $0.104^{* * *}$ & $0.021^{* * *}$ & 0.009 & $0.128^{* * *}$ & $0.104^{* * * *}$ & -0.008 & $0.124^{* * *}$ \\
\hline Non-executives & $(0.013)$ & $(0.048)$ & $(0.011)$ & $\begin{array}{l}(0.011) \\
-1.548^{* * *}\end{array}$ & $(0.007)$ & $(0.044)$ & $(0.011)$ & $(0.013)$ & $(0.054)$ & $(0.011)$ \\
\hline & & & & $(0.114)$ & & & & & & \\
\hline $\begin{array}{l}\text { Non-executives } \times \\
\text { Acquisition experience }(\mathrm{H} 2)\end{array}$ & & & & $\begin{array}{l}0.011^{*} \\
(0.006)\end{array}$ & & & & & & \\
\hline $\begin{array}{l}\text { Experience with successful and } \\
\text { average acquisitions (H3) }\end{array}$ & & & & & $\begin{array}{l}0.021^{* * *} \\
(0.007)\end{array}$ & $\begin{array}{l}0.025 \\
(0.021)\end{array}$ & $\begin{array}{l}0.015^{* *} \\
(0.006)\end{array}$ & & & \\
\hline Firms' acquisition experience & & & & & & & & $0.003^{* *}$ & $0.006^{*}$ & 0.002 \\
\hline $\begin{array}{l}\text { Acquisition experience (directors) } \times \\
\text { firm's acquisition experience }(\mathrm{H} 4)\end{array}$ & & & & & & & & $\begin{array}{l}(0.001) \\
-0.0001^{* *} \\
(0.000)\end{array}$ & $\begin{array}{l}(0.003) \\
-0.0001 \\
(0.000)\end{array}$ & $\begin{array}{l}(0.001) \\
-0.0001^{* *} \\
(0.000)\end{array}$ \\
\hline Director traits & Yes & Yes & Yes & Yes & Yes & Yes & Yes & Yes & Yes & Yes \\
\hline Board characteristics & Yes & Yes & Yes & Yes & Yes & Yes & Yes & Yes & Yes & Yes \\
\hline Financial information & Yes & Yes & Yes & Yes & Yes & Yes & Yes & Yes & Yes & Yes \\
\hline Ownership structure & Yes & Yes & Yes & Yes & Yes & Yes & Yes & Yes & Yes & Yes \\
\hline Constant & $\begin{array}{l}3.360 \\
(3.544)\end{array}$ & $\begin{array}{l}6.182 \\
(5.837)\end{array}$ & $\begin{array}{l}-2.016 \\
(4.153)\end{array}$ & $\begin{array}{l}2.856 \\
(3.348)\end{array}$ & $\begin{array}{l}2.828 \\
(3.565)\end{array}$ & $\begin{array}{l}6.350 \\
(5.766)\end{array}$ & $\begin{array}{l}-2.554 \\
(4.187)\end{array}$ & $\begin{array}{l}2.952 \\
(3.562)\end{array}$ & $\begin{array}{l}6.482 \\
(5.900)\end{array}$ & $\begin{array}{l}-2.450 \\
(4.157)\end{array}$ \\
\hline Director * firm FE & Yes & Yes & Yes & Yes & Yes & Yes & Yes & Yes & Yes & Yes \\
\hline Year FE & Yes & Yes & Yes & Yes & Yes & Yes & Yes & Yes & Yes & Yes \\
\hline$N$ & 28,080 & 9839 & 18,241 & 28,080 & 28,080 & 9839 & 18,241 & 28,080 & 9839 & 18,241 \\
\hline
\end{tabular}

We use 2SLS regression to address endogeneity issues. In the first stage, we regress acquisition experience on the instrumental variable 'Acquisition active period'. The fitted value of acquisition experience is included in the second stage. The following table presents the 2 nd stage regressions explaining directors' (ln) total compensation by fitted acquisition experience measures and a set of control variables. The structure of the table is similar to Table 6 . We control for director traits, board characteristics, financial information and ownership structure. Time and director* firm fixed effects are included. Variable definitions are given in Appendix 1. Standard errors are clustered at the firm-director level and reported in parentheses. Significance at the 1\%, 5\%, and 10\% level is indicated by $* * *, * *$, and $*$, respectively.

compensation in the year when an acquisition was completed. But such a temporary increase in compensation is unlikely to have long-lasting effect. Therefore, the number of merger waves may be a valid instrumental variable for acquisition experience. We follow Harford (2005) in identifying periods with intense acquisition activity and partition the sample window into two intervals: before the financial crisis (1999-2007) and afterwards (2008-2016). We further sub-divide each interval into two-year periods (i.e., 1999-2000, 2000-2001, etc.) (Mitchell and Mulherin, 1996). For each two-year period and industry, we then count the number of acquisitions. The two-year period within each interval in which an industry has most acquisitions is labelled as an active period for that industry. In a next step, we count the number of active periods that an individual director has experienced in his career. We find that $44 \%$ of the directors never experienced any active periods, while at the other extreme, six most connected directors have experienced as many as seven active periods. In the first stage regression, we regress a director's acquisition experience on our exogenous variable ('acquisition active period'). In the second stage, we include the fitted value of director's acquisitions from the first regression. We can thus retest the base models of Table 3 as well as all the extended models presented in the subsequent Tables $4-6 .^{7}$ The results of this instrumental variable analysis, presented in Table 7, broadly confirm all of previous results on the four hypotheses.

\subsubsection{Future acquisitions}

The reason firms pay a higher remuneration for directors' acquisition experience must be that they expect that this investment in expertise will be valuable in the future, which is the case if the firm anticipates making takeover bids. We investigate if firms executing their acquisition plans (ex post) did indeed pay more for acquisition experience ex ante. We

\footnotetext{
${ }^{7}$ Exception is the models testing for $\mathrm{H} 3$, as these specifications include two measures of experience (experience with unsuccessful acquisitions versus other experience) that are related to our exogenous variable. To circumvent this problem, we rely only on experience with successful and average acquisitions in both stages of our regression framework.
} 
Table 8

Future acquisitions.

\begin{tabular}{|c|c|c|c|c|c|c|}
\hline Dep. Variable: $(\ln )$ total compensation & $(1)$ & $(2)$ & $(3)$ & $(4)$ & $(5)$ & $(6)$ \\
\hline Sample group: & All & Execs & Non-execs & All & Execs & Non-execs \\
\hline \multirow[t]{2}{*}{ Acquisition experience (number) } & $0.011^{* * *}$ & $0.006^{* *}$ & $0.010^{* * *}$ & $0.010^{* * *}$ & $0.004^{*}$ & $0.010^{* * *}$ \\
\hline & $(0.002)$ & $(0.003)$ & $(0.002)$ & $(0.002)$ & $(0.002)$ & $(0.002)$ \\
\hline \multirow[t]{2}{*}{ Future acquisitions (over next year) } & $0.009^{*}$ & 0.009 & 0.005 & & & \\
\hline & $(0.005)$ & $(0.009)$ & $(0.005)$ & & & \\
\hline \multirow{2}{*}{$\begin{array}{l}\text { Acquisition experience } \times \\
\text { Future acquisitions (over next year) }\end{array}$} & 0.000 & $0.001^{*}$ & -0.000 & & & \\
\hline & $(0.000)$ & $(0.001)$ & $(0.000)$ & & & \\
\hline \multirow[t]{2}{*}{ Future acquisitions (over next two years) } & & & & -0.002 & -0.009 & 0.001 \\
\hline & & & & $(0.005)$ & $(0.008)$ & $(0.006)$ \\
\hline \multirow{2}{*}{$\begin{array}{l}\text { Acquisition experience } \times \\
\text { Future acquisitions (over next two years) }\end{array}$} & & & & $0.001^{*}$ & $0.002^{* * *}$ & 0.000 \\
\hline & & & & $(0.000)$ & $(0.001)$ & $(0.000)$ \\
\hline Director traits & Yes & Yes & Yes & Yes & Yes & Yes \\
\hline Board characteristics & Yes & Yes & Yes & Yes & Yes & Yes \\
\hline Financial information & Yes & Yes & Yes & Yes & Yes & Yes \\
\hline Ownership structure & Yes & Yes & Yes & Yes & Yes & Yes \\
\hline \multirow[t]{2}{*}{ Constant } & 3.782 & 5.884 & -0.831 & 3.904 & 6.261 & -1.082 \\
\hline & $(3.384)$ & $(5.275)$ & $(4.098)$ & (3.598) & $(5.543)$ & $(4.390)$ \\
\hline Director * firm FE & Yes & Yes & Yes & Yes & Yes & Yes \\
\hline Year FE & Yes & Yes & Yes & Yes & Yes & Yes \\
\hline$R^{2}$ & 0.175 & 0.159 & 0.256 & 0.172 & 0.159 & 0.250 \\
\hline$N$ & 28,522 & 9953 & 18,569 & 26,410 & 9360 & 17,050 \\
\hline
\end{tabular}

This table presents regressions explaining directors' ( In) total compensation by acquisition experience measures and a set of control variables. In models (1)-(3), Future acquisitions refer to the number of acquisitions a company will announce over the next financial year. In models (4)-(6), Future acquisitions refer to the number of acquisitions a company will announce over the next two years. We control for director traits, board characteristics, financial information and ownership structure. Time, and director ${ }^{*}$ firm fixed effects are included. Detailed variable definitions are given in Appendix 1 . Standard errors are clustered at the firm level and reported in parentheses. Significance at the $1 \%, 5 \%$, and $10 \%$ level is indicated by $* * *, * *$, and $*$, respectively

introduce a new variable, Future acquisitions, which captures the number of acquisitions that the company will announce in the following financial year (Models (1)-(3)) and the subsequent two years (Models (4)-(6)). In Table 8, we document that acquisition experience is indeed priced in the remuneration contact and that this is even more so the case - especially for executive directors - if the firm does indeed make acquisitions in the subsequent years (as the interaction term in Models (2), (4) and (5) indicates). This result reinforces our claim that companies pay directors a premium for valuable relevant takeover experience.

\subsubsection{Alternative measures of acquisition experience}

We retest our baseline models of Table 3 by means of different measures of acquisition experience. Specifically, we focus on (i) experience with large acquisitions, (ii) experience with completed acquisitions (relative to acquisition attempts for which takeover negotiations failed), and (iii) an experience measure generated from a factor analysis on the total number of acquisitions, the number of large acquisitions, and the number of completed acquisitions (Models (1) to (3) of Table 9). All experience coefficients are positively statistically significant at the one percent level. In addition, we test two additional experience measures that capture the breadth (involvement in cross-industry or cross-border acquisitions) and depth (involvement in within-industry or domestic acquisitions) of directors' acquisition experience and report in Models (4) and (5) results qualitatively similar to the baseline regressions. As our acquisition experience measure considers all acquisition transactions a director has undertaken since the beginning of the acquisitions database (1978), we may have overstated older directors' acquisition experience if the value of experience decays over time. To address this issue, we generate rolling windows of acquisition experience that dissect the experience into the one gained over the most recent three years, four to five years ago, and beyond. ${ }^{8}$ In Table 9 (Model (6)), we demonstrate that director compensation remains significantly positively related to measures of recent acquisition experience. Moreover, when we compare the coefficients of experience by time period, we observe that experience in recent years is more strongly priced in the remuneration contract, which suggests that the value of experience decays overtime.

Lastly, we investigate directors' acquisition experience from a target perspective as they may have been serving on the board of a target that received a takeover offer. The number of (announced) acquisitions a director has experienced when being on the board of the target company (as an executive or a non-executive director) stands for target acquisition expe-

\footnotetext{
${ }^{8}$ Since we do not have sufficient data in such rolling windows for observations at the beginning of the sample period, these observations are removed.
} 
Table 9

Alternative measures of acquisition experience.

\begin{tabular}{|c|c|c|c|c|c|c|c|}
\hline Dep. Variable: (ln) total compensation & $(1)$ & $(2)$ & $(3)$ & $(4)$ & $(5)$ & $(6)$ & $(7)$ \\
\hline $\begin{array}{l}\text { Sample group } \\
\text { Acquisition experience (large) }\end{array}$ & $\begin{array}{l}\text { All } \\
0.020^{* * *}\end{array}$ & All & All & All & All & All & All \\
\hline & $(0.004)$ & & & & & & \\
\hline Acquisition experience (complete) & & $0.010^{* * *}$ & & & & & \\
\hline \multirow[t]{2}{*}{ Acquisition experience (factor) } & & $(0.002)$ & $0.087^{* * *}$ & & & & \\
\hline & & & $(0.013)$ & & & & \\
\hline \multirow[t]{2}{*}{ Deep acquisition experience } & & & & $0.075^{* * *}$ & & & \\
\hline & & & & $(0.013)$ & & & \\
\hline \multirow[t]{2}{*}{ Broad acquisition experience } & & & & & $0.099^{* * *}$ & & \\
\hline & & & & & $(0.015)$ & & \\
\hline \multirow[t]{2}{*}{ Acquisition experience (recent 3 years) } & & & & & & $0.010^{* * *}$ & \\
\hline & & & & & & $(0.002)$ & \\
\hline \multirow[t]{2}{*}{ Acquisition experience (recent $4-5$ years) } & & & & & & $0.008^{* * *}$ & \\
\hline & & & & & & $(0.002)$ & \\
\hline Acquisition experience (beyond 5 years) & & & & & & $\begin{array}{l}0.007^{* * *} \\
(0.002)\end{array}$ & \\
\hline \multirow[t]{2}{*}{ Acquisition experience (target) } & & & & & & & $0.069^{* * *}$ \\
\hline & & & & & & & $(0.024)$ \\
\hline Director traits & Yes & Yes & Yes & Yes & Yes & Yes & Yes \\
\hline Board characteristics & Yes & Yes & Yes & Yes & Yes & Yes & Yes \\
\hline Financial information & Yes & Yes & Yes & Yes & Yes & Yes & Yes \\
\hline Ownership structure & Yes & Yes & Yes & Yes & Yes & Yes & Yes \\
\hline Constant & $\begin{array}{l}4.447 \\
(3.371)\end{array}$ & $\begin{array}{l}4.066 \\
(3.378)\end{array}$ & $\begin{array}{l}4.014 \\
(3.362)\end{array}$ & $\begin{array}{l}4.244 \\
(3.389)\end{array}$ & $\begin{array}{l}4.144 \\
(3.361)\end{array}$ & $\begin{array}{l}3.624 \\
(3.407)\end{array}$ & $\begin{array}{l}4.407 \\
(3.398)\end{array}$ \\
\hline Director * firm FE & Yes & Yes & Yes & Yes & Yes & Yes & Yes \\
\hline Year FE & Yes & Yes & Yes & Yes & Yes & Yes & Yes \\
\hline$R^{2}$ & 0.173 & 0.175 & 0.176 & 0.175 & 0.176 & 0.173 & 0.172 \\
\hline$N$ & 28,522 & 28,522 & 28,522 & 28,522 & 28,522 & 28,401 & 28,522 \\
\hline
\end{tabular}

This table presents regressions explaining directors' (ln) total compensation by acquisition experience measures and a set of control variables. In each model, we focus on one specific acquisition experience measure, which are defined in Section 3.2 and Appendix 1. We control for director traits, board characteristics, financial information and ownership structure. Time and director * firm fixed effects are included. All variable definitions are given in Appendix 1. Standard errors are clustered at the firm-director level and reported in parentheses. Significance at the $1 \%, 5 \%$, and $10 \%$ level is indicated by $* * *$, $* *$, and $*$, respectively.

rience. In Model (7) of Table 9, we find that target acquisition experience is also positively related to total compensation, implying that the experience of having worked in a target firm may also be valuable.

\subsubsection{The impact of directors' committee membership}

In the basic model, we have included dummy variables capturing directors' committee membership to rule out the possibility that committee membership explains the remuneration attributed to non-executive directors' acquisition experience. We constructed (1) a dummy indicating whether a director served on any committee and (2) a dummy indicating whether a director served on the audit committee. When we included either of these variables in our models (not tabulated), all previous results on the impact of acquisition experience remain qualitatively similar.

\subsubsection{The quality of corporate governance}

In our analysis, we implicitly assumed that firms are able to discern directors' value-adding experience. Whether or not the assumption is in place depends on the quality of corporate governance. We now capture the overall corporate governance effectiveness by means of two measures: (i) the E-index (Bebchuk et al., 2009) - a higher E-index reflects more a lower-shareholder orientation and a more entrenched management, and (ii) the Governance Pillar Index (from Refinitiv Eikon) which includes board independence, board diversity, compensation design, committee setup (audit, compensation, nomination), compensation design, shareholder rights preservation, takeover defenses, a CSR index (based on strategy, reporting and transparency). Table 10, panels A and B, respectively show the impact of the E-index and the Governance Pillar index. We observe that the overall corporate governance quality does not affect the findings we showed in Table 3. 


\subsubsection{CEO power}

The advisory role of non-executive directors could be eroded or ignored by a powerful CEO. Therefore, it may be important to control for CEO power for which we create two measures. The first one is a power index that aggregates six provisions (Finkelstein, 1992; Adams, Almeida and Ferreira, 2005): (i) the CEO is the only executive director on the board, (ii) the CEO is

Table 10

The Quality of Corporate Governance.

\begin{tabular}{|c|c|c|c|c|c|c|c|c|c|c|}
\hline Panel A & $(1)$ & $(2)$ & (3) & $(4)$ & $(5)$ & $(6)$ & $(7)$ & $(8)$ & (9) & $(10)$ \\
\hline Sample group: & All & Execs & $\begin{array}{l}\text { Non- } \\
\text { execs }\end{array}$ & All & All & Execs & $\begin{array}{l}\text { Non- } \\
\text { execs }\end{array}$ & All & Execs & $\begin{array}{l}\text { Non- } \\
\text { execs }\end{array}$ \\
\hline \multirow[t]{2}{*}{ Acquisition experience (number) (H1) } & $0.011^{* * *}$ & $0.005^{* *}$ & $0.010^{* * *}$ & 0.002 & & & & $0.013^{* * *}$ & $0.006^{* *}$ & $0.012^{* * *}$ \\
\hline & $(0.002)$ & $(0.002)$ & $(0.002)$ & $\begin{array}{l}(0.003) \\
-1.564^{* * *}\end{array}$ & & & & $(0.002)$ & $(0.003)$ & $(0.002)$ \\
\hline Non-executives & & & & $(0.104)$ & & & & & & \\
\hline \multirow{2}{*}{$\begin{array}{l}\text { Non-executives } \times \\
\quad \text { Acquisition experience }(\mathrm{H} 2)\end{array}$} & & & & $0.010^{* * * *}$ & & & & & & \\
\hline & & & & $(0.003)$ & & & & & & \\
\hline \multirow[t]{2}{*}{$\begin{array}{l}\text { Successful and normal acquisition } \\
\text { experience }(\mathrm{H} 3)\end{array}$} & & & & & $0.008^{* * *}$ & 0.002 & $0.008^{* * *}$ & & & \\
\hline & & & & & $(0.002)$ & $(0.003)$ & $(0.002)$ & & & \\
\hline \multirow[t]{2}{*}{ Unsuccessful acquisition experience } & & & & & 0.015 & 0.020 & 0.002 & & & \\
\hline & & & & & $(0.012)$ & $(0.018)$ & $(0.013)$ & & & \\
\hline \multirow[t]{2}{*}{ Firms' acquisition experience } & & & & & & & & $0.002^{* * *}$ & $0.003^{* * *}$ & $0.001^{*}$ \\
\hline & & & & & & & & $(0.000)$ & $(0.001)$ & $(0.000)$ \\
\hline \multirow[t]{2}{*}{$\begin{array}{l}\text { Directors' acquisition experience } \times \\
\quad \text { firms' acquisition experience }(\mathrm{H} 4)\end{array}$} & & & & & & & & $-0.001^{* * *}$ & -0.001 & $-0.001^{* * *}$ \\
\hline & & & & & & & & $(0.000)$ & $(0.000)$ & $(0.000)$ \\
\hline E-index & $\begin{array}{l}0.019 \\
(0.011)\end{array}$ & $\begin{array}{l}0.027 \\
(0.018)\end{array}$ & $\begin{array}{l}0.012 \\
(0.012)\end{array}$ & $\begin{array}{l}0.015 \\
(0.010)\end{array}$ & $\begin{array}{l}0.019^{*} \\
(0.011)\end{array}$ & $\begin{array}{l}0.029 \\
(0.018)\end{array}$ & $\begin{array}{l}0.012 \\
(0.012)\end{array}$ & $\begin{array}{l}0.019^{*} \\
(0.011)\end{array}$ & $\begin{array}{l}0.026 \\
(0.018)\end{array}$ & $\begin{array}{l}0.013 \\
(0.012)\end{array}$ \\
\hline Director characteristics & Yes & Yes & Yes & Yes & Yes & Yes & Yes & Yes & Yes & Yes \\
\hline Board characteristics & Yes & Yes & Yes & Yes & Yes & Yes & Yes & Yes & Yes & Yes \\
\hline Financial information & Yes & Yes & Yes & Yes & Yes & Yes & Yes & Yes & Yes & Yes \\
\hline Ownership structure & Yes & Yes & Yes & Yes & Yes & Yes & Yes & Yes & Yes & Yes \\
\hline Constant & $\begin{array}{l}3.828 \\
(3.375)\end{array}$ & $\begin{array}{l}5.860 \\
(5.267)\end{array}$ & $\begin{array}{l}-0.730 \\
(4.098)\end{array}$ & $\begin{array}{l}3.246 \\
(3.218)\end{array}$ & $\begin{array}{l}3.846 \\
(3.373)\end{array}$ & $\begin{array}{l}5.870 \\
(5.294)\end{array}$ & $\begin{array}{l}-0.685 \\
(4.107)\end{array}$ & $\begin{array}{l}3.902 \\
(3.369)\end{array}$ & $\begin{array}{l}6.210 \\
(5.240)\end{array}$ & $\begin{array}{l}-0.711 \\
(4.087)\end{array}$ \\
\hline Director FE & Yes & Yes & Yes & Yes & Yes & Yes & Yes & Yes & Yes & Yes \\
\hline Year FE & Yes & Yes & Yes & Yes & Yes & Yes & Yes & Yes & Yes & Yes \\
\hline$R 2$ & 0.174 & 0.157 & 0.256 & 0.246 & 0.173 & 0.156 & 0.255 & 0.175 & 0.159 & 0.257 \\
\hline$N$ & $\begin{array}{l}28,522 \\
(3)\end{array}$ & $\begin{array}{l}9953 \\
(1)\end{array}$ & $\begin{array}{l}18,569 \\
(2)\end{array}$ & $\begin{array}{l}28,522 \\
(4)\end{array}$ & $\begin{array}{l}28,522 \\
(7)\end{array}$ & $\begin{array}{l}9953 \\
(5)\end{array}$ & $\begin{array}{l}18,569 \\
(6)\end{array}$ & $\begin{array}{l}28,522 \\
(10)\end{array}$ & $\begin{array}{l}9953 \\
(8)\end{array}$ & $\begin{array}{l}18,569 \\
(9)\end{array}$ \\
\hline $\begin{array}{l}\text { Panel B } \\
\text { Sample group: }\end{array}$ & All & Execs & $\begin{array}{l}\text { Non- } \\
\text { execs }\end{array}$ & All & All & Execs & $\begin{array}{l}\text { Non- } \\
\text { execs }\end{array}$ & All & Execs & $\begin{array}{l}\text { Non- } \\
\text { execs }\end{array}$ \\
\hline Acquisition experience (number) (H1) & $\begin{array}{l}0.008^{* * *} \\
(0.002)\end{array}$ & $\begin{array}{l}-0.001 \\
(0.003)\end{array}$ & $\begin{array}{l}0.008^{* * *} \\
(0.002)\end{array}$ & $\begin{array}{l}-0.005^{*} \\
(0.003)\end{array}$ & & & & $\begin{array}{l}0.010^{* * *} \\
(0.002)\end{array}$ & $\begin{array}{l}0.001 \\
(0.004)\end{array}$ & $\begin{array}{l}0.010^{* * *} \\
(0.003)\end{array}$ \\
\hline Non-executives & & & & $\begin{array}{l}-1.810^{* * *} \\
(0.158)\end{array}$ & & & & & & \\
\hline $\begin{array}{l}\text { Non-executives } \times \\
\quad \text { Acquisition experience }(\mathrm{H} 2)\end{array}$ & & & & $\begin{array}{l}0.015^{* * *} \\
(0.003)\end{array}$ & & & & & & \\
\hline $\begin{array}{l}\text { Successful and normal acquisition } \\
\text { experience (H3) }\end{array}$ & & & & & $\begin{array}{l}0.006^{* * *} \\
(0.002)\end{array}$ & $\begin{array}{l}-0.004 \\
(0.003)\end{array}$ & $\begin{array}{l}0.007^{* * *} \\
(0.002)\end{array}$ & & & \\
\hline Unsuccessful acquisition experience & & & & & $\begin{array}{l}0.013 \\
(0.015)\end{array}$ & $\begin{array}{l}0.005 \\
(0.024)\end{array}$ & $\begin{array}{l}-0.003 \\
(0.017)\end{array}$ & & & \\
\hline Firms' acquisition experience & & & & & & & & $\begin{array}{l}0.001^{* * *} \\
(0.000)\end{array}$ & $\begin{array}{l}0.004^{* * *} \\
(0.001)\end{array}$ & $\begin{array}{l}0.001 \\
(0.001)\end{array}$ \\
\hline $\begin{array}{l}\text { Directors' acquisition experience } \times \\
\quad \text { firms' acquisition experience }(\mathrm{H} 4)\end{array}$ & & & & & & & & $\begin{array}{l}-0.001^{*} \\
(0.000)\end{array}$ & $\begin{array}{l}-0.001 \\
(0.000)\end{array}$ & $\begin{array}{l}-0.001 \\
(0.000)\end{array}$ \\
\hline Governance pillar index & $\begin{array}{l}0.001 \\
(0.000)\end{array}$ & $\begin{array}{l}0.001 \\
(0.001)\end{array}$ & $\begin{array}{l}-0.001 \\
(0.000)\end{array}$ & $\begin{array}{l}0.001 \\
(0.000)\end{array}$ & $\begin{array}{l}0.001 \\
(0.000)\end{array}$ & $\begin{array}{l}0.001 \\
(0.001)\end{array}$ & $\begin{array}{l}-0.001 \\
(0.000)\end{array}$ & $\begin{array}{l}0.001 \\
(0.000)\end{array}$ & $\begin{array}{l}0.001 \\
(0.001)\end{array}$ & $\begin{array}{l}-0.001 \\
(0.000)\end{array}$ \\
\hline Director characteristics & Yes & Yes & Yes & Yes & Yes & Yes & Yes & Yes & Yes & Yes \\
\hline Board characteristics & Yes & Yes & Yes & Yes & Yes & Yes & Yes & Yes & Yes & Yes \\
\hline Financial information & Yes & Yes & Yes & Yes & Yes & Yes & Yes & Yes & Yes & Yes \\
\hline Ownership structure & Yes & Yes & Yes & Yes & Yes & Yes & Yes & Yes & Yes & Yes \\
\hline Constant & $\begin{array}{l}4.416 \\
(5.138)\end{array}$ & $\begin{array}{l}-4.575 \\
(7.954)\end{array}$ & $\begin{array}{l}11.736^{*} \\
(6.909)\end{array}$ & $\begin{array}{l}5.104 \\
(5.384)\end{array}$ & $\begin{array}{l}4.513 \\
(5.109)\end{array}$ & $\begin{array}{l}-4.188 \\
(7.977)\end{array}$ & $\begin{array}{l}11.678^{*} \\
(7.063)\end{array}$ & $\begin{array}{l}4.488 \\
(5.108)\end{array}$ & $\begin{array}{l}-4.424 \\
(7.823)\end{array}$ & $\begin{array}{l}11.776^{*} \\
(6.869)\end{array}$ \\
\hline
\end{tabular}


Table 10 (continued)

\begin{tabular}{|c|c|c|c|c|c|c|c|c|c|c|}
\hline Panel A & (1) & $(2)$ & (3) & (4) & (5) & (6) & (7) & $(8)$ & (9) & $(10)$ \\
\hline Director FE & Yes & Yes & Yes & Yes & Yes & Yes & Yes & Yes & Yes & Yes \\
\hline Year FE & Yes & Yes & Yes & Yes & Yes & Yes & Yes & Yes & Yes & Yes \\
\hline$R 2$ & 0.194 & 0.191 & 0.282 & 0.257 & 0.193 & 0.192 & 0.281 & 0.195 & 0.195 & 0.283 \\
\hline$N$ & 12,675 & 4609 & 8066 & 12,675 & 12,675 & 4609 & 8066 & 12,675 & 4609 & 8066 \\
\hline
\end{tabular}

This table shows the regression results explaining directors' (In) total compensation by acquisition experience measures and a set of control variables. To proxy for the quality of corporate governance, we use a self-calculated E-index (Panel A) and Governance pillar index (Panel B). The table retest the models presented in Tables 1-3 while controlling for director traits, board characteristics, financial information and ownership structure. Time, and director * firm fixed effects are included. Variable definitions are given in Appendix 1. Standard errors are clustered at the firm-director level and reported in parentheses. Significance at the $1 \%, 5 \%$, and $10 \%$ level is indicated by $* * *, * *$, and $*$, respectively.

Table 11

CEO Power.

\begin{tabular}{|c|c|c|c|c|c|c|c|}
\hline & (1) & (2) & (3) & (4) & (5) & (6) & (7) \\
\hline Sample group & All & Exec & Non-execs & All & Exec & Non-execs & All \\
\hline \multirow[t]{2}{*}{ Acquisition experience (number) } & $0.010^{* * *}$ & $0.006^{* *}$ & $0.010^{* * * *}$ & $0.011^{* * *}$ & $0.005^{* *}$ & $0.009^{* * *}$ & $0.009^{* * *}$ \\
\hline & $(0.002)$ & $(0.002)$ & $(0.002)$ & $(0.002)$ & $(0.002)$ & $(0.002)$ & $(0.002)$ \\
\hline \multirow[t]{2}{*}{ CEO power (index) } & $-0.021^{* *}$ & 0.025 & 0.011 & & & & $-0.028^{* *}$ \\
\hline & $(0.011)$ & $(0.015)$ & $(0.008)$ & & & & $(0.012)$ \\
\hline \multirow[t]{2}{*}{ Acquisition experience $\times$ CEO power (index) } & 0.001 & & & & & & 0.001 \\
\hline & $(0.001)$ & & & & & & $(0.001)$ \\
\hline \multirow[t]{2}{*}{ CEO power (centrality) } & & & & $-0.161^{*}$ & 0.013 & $-0.226^{* * *}$ & $-0.154^{*}$ \\
\hline & & & & $(0.091)$ & $(0.122)$ & $(0.066)$ & $(0.091)$ \\
\hline \multirow[t]{2}{*}{ Acquisition experience $\times$ CEO power (centrality) } & & & & 0.001 & & & 0.001 \\
\hline & & & & $(0.004)$ & & & $(0.004)$ \\
\hline Director characteristics & Yes & Yes & Yes & Yes & Yes & Yes & Yes \\
\hline Board characteristics & Yes & Yes & Yes & Yes & Yes & Yes & Yes \\
\hline Financial information & Yes & Yes & Yes & Yes & Yes & Yes & Yes \\
\hline Ownership structure & Yes & Yes & Yes & Yes & Yes & Yes & Yes \\
\hline Constant & $\begin{array}{l}3.667 \\
(3.384)\end{array}$ & $\begin{array}{l}6.234 \\
(5.263)\end{array}$ & $\begin{array}{l}-0.789 \\
(4.102)\end{array}$ & $\begin{array}{l}3.894 \\
(3.184)\end{array}$ & $\begin{array}{l}0.116 \\
(3.785)\end{array}$ & $\begin{array}{l}3.838 \\
(4.106)\end{array}$ & $\begin{array}{l}3.762 \\
(3.178)\end{array}$ \\
\hline Director FE & Yes & Yes & Yes & Yes & Yes & Yes & Yes \\
\hline Year FE & Yes & Yes & Yes & Yes & Yes & Yes & Yes \\
\hline$R^{2}$ & 0.174 & 0.157 & 0.256 & 0.183 & 0.174 & 0.265 & 0.183 \\
\hline$N$ & 28,522 & 9953 & 18,569 & 23,430 & 9149 & 14,281 & 23,430 \\
\hline
\end{tabular}

This table shows the regression results explaining directors' (In) total compensation by acquisition experience measures and a set of control variables. To proxy for the CEO's power, we use a CEO power index based on six provisions and CEO's director network strength (measured by eigenvector centrality measure). We control for director traits, board characteristics, financial information and ownership structure. Time, and director * firm fixed effects are included. Variable definitions are given in Appendix 1. Standard errors are clustered at the firm-director level and reported in parentheses. Significance at the $1 \%, 5 \%$, and $10 \%$ level is indicated by $* * *, * *$, and $*$, respectively.

also the chairman of the board, (iii) the CEO's tenure is longer than the median CEO tenure of the industry (by year), (iv) the CEO's tenure is longer than the average tenure of the board, $(v)$ the percentage of independent directors among all nonexecutive directors is less than 75\%, and (vi) the CEO's share ownership is greater than the median CEO ownership of the industry (by year). The second CEO power measure is based on the CEO's network (Brown et al., 2012; Renneboog and Zhao 2014, 2020; Goergen et al. 2019). We consider executive and non-executive directors sitting on the same board as being connected. Consequently, directors with multiple directorships and those connected to other well-connected directors have a high eigenvector centrality score (in the matrix of all the connections between non-executive and executive directors). We consider the CEO's eigenvector centrality measure as a CEO power measure.

In Table 11 Model (1), we show the negative effect CEO power (as represented by the above first power index) on director compensation. However, it does not materially affect the positive relation between acquisition experience and remuneration, as the coefficient of acquisition experience remains statistically significant and retains its magnitude, while the interaction between acquisition experience and CEO power is not statistically significant. Likewise, we find that non-executive director compensation is reduced when the CEO has a high eigenvector network score (Model (6)). Both CEO power measures capture a different kind of power as the measures are not strongly correlated, which is why we can include both in one model (Model (7)). Again we find that the interaction between the power measures and acquisition experience is not statistically significant and that the relation between remuneration and acquisition experience is upheld. 
Table 12

. CEO's Attitude towards Delegation and Consultation.

\begin{tabular}{|c|c|c|c|c|c|c|c|c|}
\hline & (3) & $(1)$ & $(2)$ & $(4)$ & $(7)$ & $(5)$ & (6) & $(8)$ \\
\hline Sample group: & All & Execs & Non-execs & All & All & Execs & Non-execs & All \\
\hline \multirow[t]{2}{*}{ Acquisition experience (number) } & $0.011^{* * *}$ & $0.006^{* *}$ & $0.010^{* * *}$ & $0.011^{* * *}$ & $0.011^{* * *}$ & $0.005^{* *}$ & $0.009^{* * *}$ & $0.010^{* * *}$ \\
\hline & $(0.002)$ & $(0.002)$ & $(0.002)$ & $(0.002)$ & $(0.002)$ & $(0.002)$ & $(0.002)$ & $(0.002)$ \\
\hline \multirow[t]{2}{*}{ CEO delegation (index) } & $-0.028^{*}$ & $-0.050^{*}$ & -0.012 & $-0.038^{*}$ & & & & \\
\hline & $(0.016)$ & $(0.030)$ & $(0.016)$ & $(0.019)$ & & & & \\
\hline \multirow[t]{2}{*}{ CEO delegation (index) $\times$ Acquisition experience } & & & & 0.001 & & & & \\
\hline & & & & $(0.002)$ & & & & \\
\hline \multirow[t]{2}{*}{ CEO delegation (centrality) } & & & & & -0.012 & -0.005 & -0.004 & -0.009 \\
\hline & & & & & $(0.012)$ & $(0.024)$ & $(0.010)$ & $(0.015)$ \\
\hline \multirow[t]{2}{*}{ CEO delegation (centrality) $\times$ Acquisition experience } & & & & & & & & -0.000 \\
\hline & & & & & & & & $(0.001)$ \\
\hline Director characteristics & Yes & Yes & Yes & Yes & Yes & Yes & Yes & Yes \\
\hline Board characteristics & Yes & Yes & Yes & Yes & Yes & Yes & Yes & Yes \\
\hline Financial information & Yes & Yes & Yes & Yes & Yes & Yes & Yes & Yes \\
\hline Ownership structure & Yes & Yes & Yes & Yes & Yes & Yes & Yes & Yes \\
\hline Constant & $\begin{array}{l}3.871 \\
(3.386)\end{array}$ & $\begin{array}{l}6.234 \\
(5.263)\end{array}$ & $\begin{array}{l}-0.786 \\
(4.106)\end{array}$ & $\begin{array}{l}3.874 \\
(3.389)\end{array}$ & $\begin{array}{l}4.086 \\
(3.193)\end{array}$ & $\begin{array}{l}0.160 \\
(3.800)\end{array}$ & $\begin{array}{l}3.916 \\
(4.127)\end{array}$ & $\begin{array}{l}4.084 \\
(3.193)\end{array}$ \\
\hline Director FE & Yes & Yes & Yes & Yes & Yes & Yes & Yes & Yes \\
\hline Year FE & Yes & Yes & Yes & Yes & Yes & Yes & Yes & Yes \\
\hline$R 2$ & 0.174 & 0.157 & 0.256 & 0.174 & 0.183 & 0.175 & 0.264 & 0.183 \\
\hline$N$ & 28,522 & 9953 & 18,569 & 28,522 & 23,395 & 9114 & 14,281 & 23,395 \\
\hline
\end{tabular}

This table shows the regression results explaining directors' (In) total compensation by acquisition experience measures and a set of control variables. To proxy for CEO's ability of delegation, we use the ratio of non-executive director power index scaled by CEO power index and the non-executive directors' network strength relative to the CEO's network strength. We control for director traits, board characteristics, financial information and ownership structure. Time, and director * firm fixed effects are included. Variable definitions are given in Appendix 1. Standard errors are clustered at the firm-director level and reported in parentheses. Significance at the $1 \%, 5 \%$, and $10 \%$ level is indicated by $* * *, * *$, and $*$, respectively.

\subsubsection{CEO's attitude towards delegation and consultation}

The value of executive and non-executive directors' acquisition experience could also depend on the CEO's attitude towards delegation, consultation, or making collegial board decisions versus a deal-maker attitude which does not leave room for input of other directors (with at the extreme a narcistic CEO as in Aktas, de Bodt, Bollaert, and Roll, 2016). In order to capture, what we call for short, delegation ability we create two measures. The first is based on the measure of CEO power and is the sum of the following four factors developed by Finkelstein (1992) and Adams, Almeida and Ferreira (2005): (i) the CEO is the only executive director on the board, (ii) the CEO is also the chairman of the board, (iii) the CEO's tenure is longer than the median CEO tenure of the industry (by year), (iv) the CEO's share ownership is greater than the median CEO ownership of the industry (by year). These factors should be taken relative to the power of all the non-executive directors, as captured by the sum of the following three factors: (i) the average tenure of non-executive directors is longer than the CEO's tenure, (ii) the percentage of independent directors among all non-executive directors is more than $75 \%$, and (iii) the nonexecutive directors' cumulative external board membership is larger than the median of the industry (by year). We then take the ratio of the non-executive directors' power and the CEO power. A second measure of CEO delegation attitude is the average eigenvector centrality of all the board members standardized by CEO's eigenvector centrality.

In the baseline regressions of Table 3, we include these two CEO 'delegation attitude' measures and present the results in Table 12. We find that the CEO delegation proxies are only weakly (at best) associated with executive compensation (the first index is statistically significant but only at the 10\% level in 3 models and the interaction term with acquisition experience is not statistically significant; the index based on centrality measures never is). In addition, controlling for these two delegation proxies does not affect the relationship between acquisition experience and compensation.

\subsubsection{The marginal effects of acquisition experience}

The marginal effect on remuneration of one additional acquisition may be different for an experienced director than for a less experienced one. To examine this point, we create three dummy variables capturing whether a director has experience with one, two or more acquisitions. The group of directors with no acquisition experience is the benchmark, and we replace the variable Acquisition Experience (number) in the baseline regressions of Table 3 by the above three dummy variables. We find that the effect of more experience increases with the number of acquisitions experienced (the coefficients of the dummy variables are all statistically significant and increase monotonically; Model (1) Table 13, below). Second, we further test the marginal effects of acquisition experience conditional on experience quantiles (terciles). In Model (2)-(4) of Table 13, we document that acquisition experience has a greater effect on compensation for directors belonging to the higher terciles of expe- 
Table 13

The Marginal Effects of Acquisition Experience.

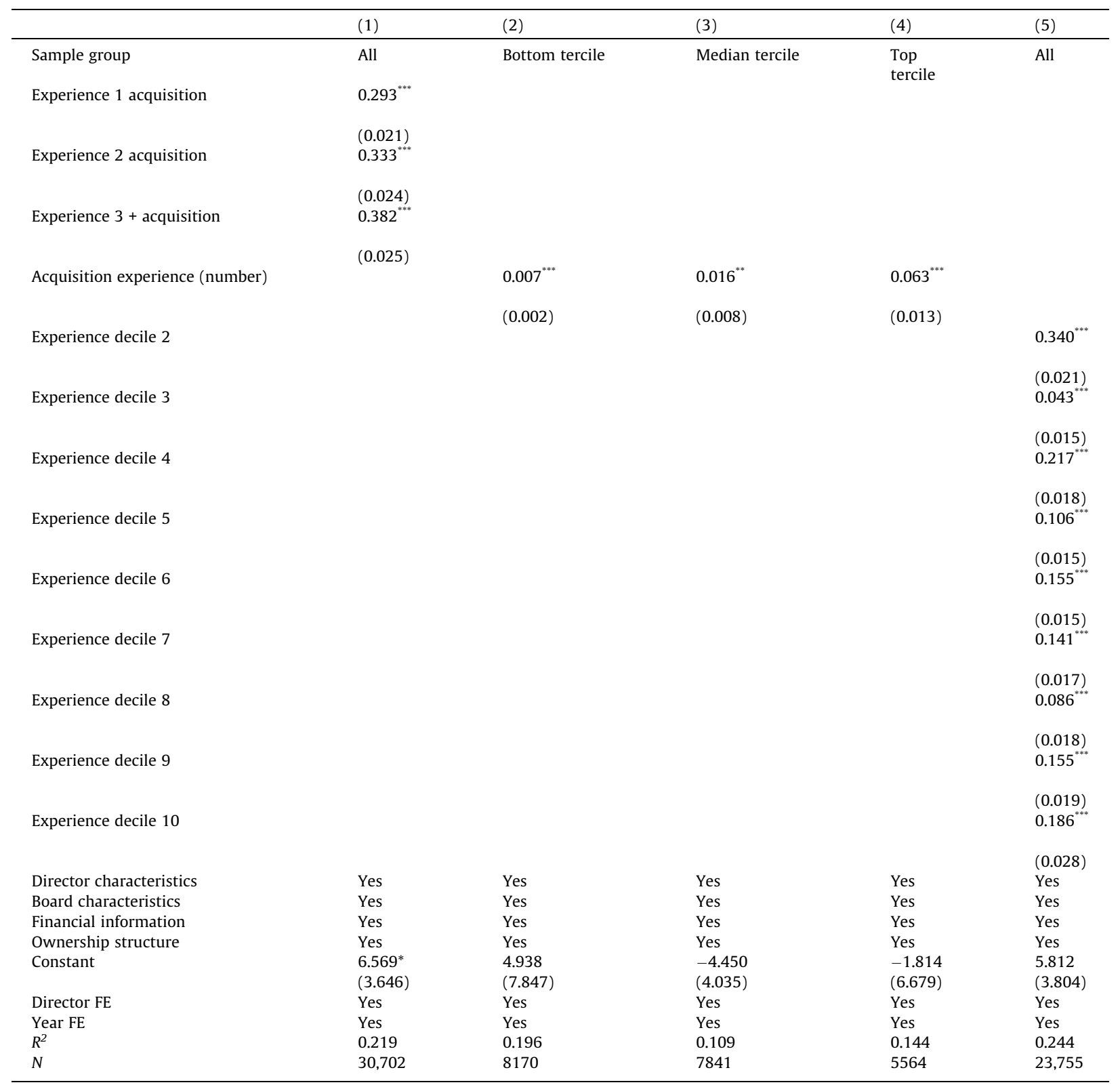

This table shows the regression results explaining directors' (In) total compensation by acquisition experience measures and a set of control variables. To evaluate the marginal effects of acquisition experience, we first estimate the effect of three dummy variables that equals one when the director has experienced one, two or three and more acquisitions (Model (1)). Second, we compare the effect of acquisition experience (number) in three terciles of director experience per industry and year (Model (2)-(4)). Third, we include nine dummy variables to test the effect of director experience in deciles (Model (5)). We control for director traits, board characteristics, financial information and ownership structure. Time, and director * firm fixed effects are included. Variable definitions are given in Appendix 1. Standard errors are clustered at the firm-director level and reported in parentheses. Significance at the $1 \%, 5 \%$, and $10 \%$ level is indicated by $* * *, * *$, and $*$, respectively.

rience. This confirms that conditional on experience, more experience is still priced in the remuneration contract. Third, we sort acquisition experience by industry and year and create dummy variables representing experience deciles (Model (5)). As some directors in our sample do not have any acquisition experience, we remove all observations with zero acquisition experience before creating acquisition experience deciles. This model tests the extent to which experience matters while one has little (lower decile) or a lot of acquisition experience (higher deciles). One could conjecture that for the lower deciles of experience additional experience is priced more than for higher deciles. However, Model (5) shows that the second decile is 
priced higher than the omitted first decile and its marginal effect is indeed higher than for decile 10, but the marginal effects of additional experience on remuneration do not linearly decline across deciles. It may be that we are now asking too much from the data as the variation of experience across deciles is not strong and the higher the experience decile, the higher the possible exposure to more unsuccessful acquisitions may occur and we know that such exposure is not priced in the remuneration contract.

\section{Discussion and conclusion}

Academic interest in the human capital of executive and non-executive directors and its returns for both directors and firms has recently regained momentum. Some recent papers show that variation in compensation is driven by differences in the value of individuals' human capital (Brockman et al., 2016; Bugeja et al., 2016; Datta and Iskandar-Datta, 2014).We still have a limited understanding of why individuals with seemingly similar human capital (based on past corporate positions or education) are paid differently within and across firms (Crocker and Eckardt, 2014; Eckardt et al., 2018). Therefore, we delve one level deeper in this study; we concentrate on a specific type of human capital, namely experience in takeovers, and examine whether acquisitions experience, which is quite heterogeneous across both executive and non-executive directors, is priced in their remuneration contracts.

We find strong results on the relation between experience and compensation: (1) acquisition experience (measured by the number of acquisitions a director has handled) increases a director's total remuneration, and this relation is relatively stronger for (2) non-executive directors than for their executive counterparts. Given that many takeovers turn out to be failures, especially for bidders when agency problems and hence the tendency by the executive to build an empire are deemed high, takeover experience may be particularly important for non-executive directors in their advisory and supervisory capacity as they ought to give advice to pursue or refrain from takeovers. (3) Only experience with non-unsuccessful takeovers is priced in directors' remuneration contracts; unsuccessful acquisitions are not rewarded and hence do not seem regarded as a learning opportunity. (4) In firms where acquisition experience is scarce, an individual's expertise is valued more compared to firms where this experience is already abundant (as measured by the firm's acquisition record or the takeover experience of the other board members). We have verified the results by examining potential endogeneity concerns, by analyzing a broad set of different views on acquisition experience (such as industry-specific, broad or international experience, experience on a target's board), and by ruling out alternative explanations (such as a director's general skills level or reputation, the CEO's power and delegation attitude, and the firm's corporate governance quality).

Our results extend the existing work on human capital and remuneration in several ways. First, so far this literature has particularly focused on the transferability of human capital (e.g. general versus specialized CEO skills) and how this matters for remuneration (Custódio et al., 2013; Datta and Iskandar-Datta, 2014). By focusing on task-specific experience, we study one of the most important tasks that both executive and non-executive directors engage in, namely corporate takeovers, and examine the extent to which this type of human capital is remunerated. In doing so, we generate new insights on the role of experience captured at the granular level of a directorship and the related remuneration contract. Using granular measures of experience can deepen our understanding of human capital and remuneration by directly measuring the tasks directors have undertaken instead of making assumptions about the type of tasks related to a particular position and presuming that individuals in that position have gained experience.

Second, we also contribute to the literature on boards, and more specifically on the difference in roles and tasks of directors. Relative to executive directors, non-executive directors with acquisition experience may curb wealth-reducing acquisitions as fiduciaries to shareholders. Moreover, in their advisory and supervisory capacity, a key strategic task of nonexecutive directors is the identification of potential takeover targets and providing advice to pursue and - maybe even more important in the wake of the overwhelming evidence of poorly performing acquisitions - refrain from a takeover to the executive directors. In line with this argument, our results suggest that firms not only consider director experience but also their potential commitment to fully deploy their expertise in the interest of the firm when determining a pay premium for a director's acquisition expertise (Hambrick et al., 2015). The implication of this finding is that a pay premium on human capital is conditional on not only the expertise that individuals hold but also on firms' expectation of whether the individual would leverage her expertise in the interest of the firm.

Third, our paper shows that firms clearly discern what they regard as relevant quality of experience (failures versus successes in undertaking acquisitions) and seem to project the capability of a director to handle future acquisitions. Several papers also document the impact of failed versus successful acquisitions in different contexts. For instance, successful past acquisitions yield a higher number of board seats to executives (Harford and Schonlau, 2013), although Mira et al. (2018) dispute this as they do not find an effect.

Fourth, theoretical advances in human-capital research underscore the need to explore the interplay between human capital at the individual and firm levels (Ployhart et al., 2014; Wright et al., 2014). This paper reveals that such an interplay exists between acquisition experience residing within the firm and at the individual director level. In this regard, our results suggest a substitution effect of knowledge at the firm and individual level: firms reduce the potential value (and consequently the pay level) they attach to individual expertise when that expertise is already abundantly present in the firm.

Finally, one could make the - probably fair - argument that remuneration may not be the most important reason for nonexecutive directors to take on directorship positions. This decision could also be driven by their interest to open up oppor- 
tunities for networking and by reputational aspects. While this may certainly be the case, we show that companies do still take into account directors' acquisition experience when pricing contracts.

\section{Declaration of Competing Interest}

The authors declare that they have no known competing financial interests or personal relationships that could have appeared to influence the work reported in this paper.

\section{Appendix 1}

Variable definitions

\begin{tabular}{l}
\hline Name \\
\hline (Ln) total compensation \\
Acquisition experience (number) \\
Acquisition experience (complete) \\
Acquisition experience (large) \\
\\
Acquisition experience (factor) \\
Deep acquisition experience \\
Broad acquisition experience \\
Acquisition experience (target) \\
Acquisition experience (recent \\
3 years) \\
Acquisition experience (recent 4- \\
5 years) \\
Acquisition experience (beyond \\
5 years) \\
Experience with unsuccessful \\
acquisitions
\end{tabular}

Experience with successful and average acquisitions

Firm's acquisition experience

Relative acquisition experience

Director's general reputation

Acquisition active periods

Future acquisitions

E-index

Governance pillar index

CEO power (index)

CEO power (centrality)

\section{Definition}

Logarithm of a director's total compensation in GBP.

The number of (announced) acquisitions a director was involved in.

The number of completed acquisitions a director was involved in.

The number of large acquisitions (above the median size) a director was involved in.

A director's overall acquisition experience calculated using a factor analysis.

A director's experience in domestic acquisitions or acquisitions within the industry.

A director's experience in foreign acquisitions or acquisitions across industries. The number of (announced) acquisitions a director was involved in as a member of target firms.

The number of acquisitions a director was involved in in the recent 3 years.

The number of acquisitions a director was involved in in the recent $4-5$ years.

The number of acquisitions a director was involved in beyond 5 years.

The number of acquisitions with a cumulative abnormal return (within 3-days around the announcement date) of at least 0.5 (Definition 1), 1 (Definition 2), or 2 (Definition 3) standard deviations below the mean. (This is counted at the director level).

The number of acquisitions that are not classified as unsuccessful experiences.

The number of acquisitions a company has made since 1978 .

A director's acquisition experience minus firm's acquisition experience.

The sum of all outside directorships (other than the one in the focal firm), each of which is multiplied by a weight based on the firm size dividend by the size of the focal firm.

The number of acquisition active periods a director has experienced. An active period is years during which acquisition activity is abnormally high in an industry. The number acquisitions a company has made in one (two) year after the focal year.

An index aggregates the following provisions: poison pill, a golden parachute, a classified board and supermajority requirements for amending the charter and bylaws.

An index obtained from Refinitiv Eikon. It assesses board independence, board diversity, compensation design, committee setup (audit, compensation, nomination), compensation design, shareholder rights preservation, takeover defenses, a CSR index (based on strategy, reporting and transparency). An index that aggregates the following provisions. (1) CEO is the only executive on board; (2) CEO-chairman duality; (3) longer CEO tenure relative to peers; (4) longer CEO tenure relative to board; (5) less than $75 \%$ non-executive directors are independent; (6) greater CEO stock ownership relative to peers.

The CEO's eigenvector centrality score in the network of executive and 
Variable definitions (continued)

\begin{tabular}{|c|c|}
\hline Name & Definition \\
\hline & nonexecutive directors. \\
\hline CEO delegation (index) & The ratio of non-executive director power index divided by CEO power. \\
\hline CEO delegation (centrality) & $\begin{array}{l}\text { The ratio of average non-executive directors' eigenvector centrality divided by the } \\
\text { CEO's eigenvector centrality. }\end{array}$ \\
\hline General skills/experience & $\begin{array}{l}\text { A measure based on a factor analysis of the past number of positions, firms, and } \\
\text { industries in which a CEO worked, and two binary variables measuring whether } \\
\text { the director held a position as CEO at a different company and whether the CEO } \\
\text { worked for a conglomerate firm (see Custódio et al., 2013) }\end{array}$ \\
\hline Tenure & A director's tenure on the current board in years. \\
\hline Age & A director's age in years. \\
\hline Director busyness & A binary variable that equals 1 if the director is on more than two boards. \\
\hline Non-executive & A binary variable that equals 1 if the director is a non-executive director. \\
\hline Non-executive (\%) & The percentage of non-executive directors on the board. \\
\hline Female (\%) & The percentage of female directors on the board. \\
\hline CEO-Chairman Duality & A binary variable that equals 1 if the CEO is also the chairman. \\
\hline ROA & Operating income divided by total assets. \\
\hline Market-to-book ratio & Market value divided by the book value of equity. \\
\hline Cash-flow variance & Logarithm of the variance in cash flows. \\
\hline Sales growth & The change in sales relative to previous financial year. \\
\hline Ownership: family & The percentage of shares owned by a family. \\
\hline Ownership: government & The percentage of shares owned by the government. \\
\hline Ownership: institution & The percentage of shares owned by financial institutions. \\
\hline Ownership: corporate & The percentage of shares owned by other corporations. \\
\hline Ownership: other & The percentage of shares owned by other types of shareholders. \\
\hline Debt ratio & Total debt divided by total assets. \\
\hline (Ln) total assets & Logarithm of total assets. \\
\hline
\end{tabular}

\section{References}

Adams, R.B., Almeida, H., Ferreira, D., 2005. Powerful CEOs and their impact on corporate performance. The Review of Financial Studies 18 (4), $1403-1432$. Aktas, N., de Bodt, E., Roll, R., 2011. Serial acquirer bidding: An empirical test of the learning hypothesis. J. Corp. Finance 17, $18-32$.

Aktas, N., de Bodt, E., Roll, R., 2009. Learning, hubris and corporate serial acquisitions. J. Corp. Finance 15, 543-561.

Aktas, N., de Bodt, E., Bollaert, H., Roll, R., 2016. CEO Narcissism and the Takeover Process: From Private Initiation to Deal Completion. J. Financ. Quant. Anal. 51, 113-137.

Armstrong, C.S., Core, J.E., Guay, W.R., 2014. Do independent directors cause improvements in firm transparency? J. Financ. Econ. 113, 383-403.

Bebchuk, L., Cohen, A., Ferrell, A., 2009. What matters in corporate governance? The Review of Financial Studies $22,783-827$.

Becker, G.S., 1995. Human capital: a theoretical and empirical analysis, with special reference to education, 3. ed., [reprint]. ed. The Univ. of Chicago Press, Chicago, Ill.

Brockman, P., Lee, H.S., Salas, J.M., 2016. Determinants of CEO compensation: Generalist-specialist versus insider-outsider attributes. J. Corp. Finance 39, $53-77$.

Brown, R., Gao, N., Lee, E., \& Stathopoulos, K. (2012). What are friends for? CEO networks, pay and corporate governance. In Corporate Governance (pp. 287307). Springer, Berlin, Heidelberg.

Bugeja, M., Fohn, S., Matolcsy, Z., 2016. Determinants of the levels and changes in non-executive director compensation. Account. Finance 56, 627-667.

Bugeja, M., Rosa, R.D.S., Lee, A., 2009. The Impact of Director Reputation and Performance on the Turnover and Board Seats of Target Firm Directors. J. Bus. Finance Account. 36, 185-209.

Burak Güner, A., Malmendier, U., Tate, G., 2008. Financial expertise of directors. J. Financ. Econ. 88, $323-354$.

Carpenter, M.A., Sanders, G., Gregersen, H.B., 2001. Bundling Human Capital with Organizational Context: The Impact of International Assignment Experience on Multinational Firm Performance and CEO Pay. Acad. Manage. J. 44, 493-511.

Cartwright, S., Schoenberg, R., 2006. Thirty Years of Mergers and Acquisitions Research: Recent Advances and Future Opportunities. Br. J. Manag. 17, S1-S5. Castanias, R., Helfat, C., 1991. Managerial Resources and Rents. Journal of Management 17, 155-171.

Coff, R., Kryscynski, D., 2011. Invited Editorial: Drilling for Micro-Foundations of Human Capital-Based Competitive Advantages. J. Manag. 37, 1429-1443.

Collins, J.D., Holcomb, T.R., Certo, S.T., Hitt, M.A., Lester, R.H., 2009. Learning by doing: Cross-border mergers and acquisitions. J. Bus. Res. 62, $1329-1334$.

Crocker, A., Eckardt, R., 2014. A multilevel investigation of individual-and unit-level human capital complementarities. J. Manag. 40, 509-530.

Custódio, C., Ferreira, M.A., Matos, P., 2013. Generalists versus specialists: Lifetime work experience and chief executive officer pay. J. Financ. Econ. 108, $471-492$.

Dass, N., Kini, O., Nanda, V., Onal, B., Wang, J., 2014. Board Expertise: Do Directors from Related Industries Help Bridge the Information Gap?. Rev Financ Stud 27, 1533-1592.

Datta, S., Iskandar-Datta, M., 2014. Upper-echelon executive human capital and compensation: Generalist vs specialist skills. Strateg. Manag. J. 35, 18531866.

Eckardt, R., Skaggs, B., Lepak, D., 2018. An examination of the firm-level performance impact of cluster hiring in knowledge-intensive firms. Acad. Manage. J. 61, 919-944.

Ericsson, K.A., Lehmann, A.C., 1996. Expert and Exceptional Performance : Evidence of Maximal Adaptation to Task Constraints. Annu. Rev. Psychol. 47, 273305.

Fama, E.F., 1980. Agency Problems and the Theory of the Firm. J. Polit. Econ. 88, 288-307. 
Fama, E.F., Jensen, M.C., 1983. Separation of Ownership and Control. J. Law Econ. 26, 301-325.

Fedaseyeu, V., Linck, J.S., Wagner, H.F., 2018. Do qualifications matter? New evidence on board functions and director compensation. J. Corp. Finance 48 $816-839$.

Field, L.C., Mkrtchyan, A., 2017. The effect of director experience on acquisition performance. J. Financ. Econ. 123, 488-511.

Ferreira, D., Ginglinger, E., Laguna, M.-A., Skalli, Y., 2020. Closing the Gap: Board Gender Quotas and Hiring Practices (SSRN Scholarly Paper No ID 2992213). https://doi.org/10.2139/ssrn.2992213.

Finkelstein, S., 1992. Power in Top Management Teams: Dimensions, Measurement, and Validation. Acad. Manage. J. 35, 505-538.

Geiler, P., Renneboog, L., 2016. Executive Remuneration and the Payout Decision. Corp. Gov. Int. Rev. 24, 42-63.

Geiler, P., Birhanu, A.G., 2020. The Role of National Corporate Governance in EU Acquisitions, in: Finkelstein, S., L. Cooper, C. (Eds.), Advances in Mergers and Acquisitions, Advances in Mergers \& Acquisitions. Emerald Publishing Limited, pp. 65-78.

Girma, S., Thompson, S., Wright, P.W., 2006. The impact of merger activity on executive pay in the United Kingdom. Economica 73, $321-339$.

Goergen, M., Renneboog, L., Zhao, Y., 2019. Insider Trading and Networked Directors. J. of Corp. Finance 56, $152-175$.

Goh, L., Gupta, A., 2016. Remuneration of non-executive directors: Evidence from the UK. Br. Account. Rev. 48, 379-399.

Greve, H.R., 2003. Organizational Learning from Performance Feedback: A Behavioral Perspective on Innovation and Change. Cambridge University Press.

Guest, P.M., 2009. The impact of mergers and acquisitions on executive pay in the United Kingdom. Economica 76, $149-175$.

Hambrick, D.C., Misangyi, V.F., Park, C.A., 2015. The Quad Model for Identifying a Corporate Director's Potential for Effective Monitoring: Toward a New Theory of Board Sufficiency. Acad. Manage. Rev. 40, 323-344.

Harford, J., Li, K., 2007. Decoupling CEO wealth and firm performance: The case of acquiring CEOs. J. Finance 62, 917-949.

Harford, J., Schonlau, R.J., 2013. Does the director labor market offer ex post settling-up for CEOs? The case of acquisitions. J. Financ. Econ. 110, 18-36.

Hayward, M.L., 2002. When do firms learn from their acquisition experience? Evidence from 1990 to 1995. Strateg. Manag. J. 23, 21-39.

Hayward, M.L.A., Hambrick, D.C., 1997. Explaining the Premiums Paid for Large Acquisitions: Evidence of CEO Hubris. Adm. Sci. Q. $42,103-127$.

Hillman, A.J., Dalziel, T., 2003. Boards of Directors and Firm Performance: Integrating Agency and Resource Dependence Perspectives. Acad. Manage. Rev. 28, 383-396.

ICGN, 2010. ICGN Non-executive Director Remuneration Guidelines and Policies. London W1B.

Johnson, R.A., Hoskisson, R.E., Hitt, M.A., 1993. Board of director involvement in restructuring: The effects of board versus managerial controls and characteristics. Strateg. Manag. J. 14, 33-50.

Khanna, P., Jones, C.D., Boivie, S., 2014. Director human capital, information processing demands, and board effectiveness. J. of Manag. 40, 557-585.

Kim, D., Alvarez, S., 2019. Can’t Buy Me Love.... or Capabilities: Acquiring Innovative Capabilities through M\&A. Acad. Manag. Proc. $2019,19438$.

King, D.R., Dalton, D.R., Daily, C.M., Covin, J.G., 2004. Meta-analyses of post-acquisition performance: indications of unidentified moderators. Strateg. Manag. J. 25, 187-200.

Kolb, A.Y., Kolb, D.A., 2005. Learning Styles and Learning Spaces: Enhancing Experiential Learning in Higher Education. Acad. Manag. Learn. Educ. 4, 193212.

Maas, A., Heugens, P., Reus, T., 2019. Viceroys or Emperors? An Institution-Based Perspective on Merger and Acquisition Prevalence and Shareholder Value. J. Manag. Stud. 56, 234-269.

Mackey, A., Molloy, J.C., Morris, S.S., 2014. Scarce human capital in managerial labor markets. J. Manag. 40, $399-421$.

Martynova, M., Renneboog, L., 2008. A century of corporate takeovers: What have we learned and where do we stand? J. Bank. Finance 32, $2148-2177$.

Martynova, M., Renneboog, L., 2011. The Performance of the European Market for Corporate Control: Evidence from the $5^{\text {th }}$ Takeover Wave. European Financial Management 17 (2), 208-260.

McDonald, M.L., Westphal, J.D., Graebner, M.E., 2008. What do they know? The effects of outside director acquisition experience on firm acquisition performance. Strateg. Manag. J. 29, 1155-1177.

McNulty, T., Pettigrew, A., 1999. Strategists on the Board. Organ. Stud. 20, 47-74.

Mira, S., Goergen, M., O’Sullivan, N., 2018. The Market for Non-Executive Directors: Does Acquisition Performance Influence Future Board Seats? Br. J. Manag. 30, 415-436.

Mitchell, M.L., Mulherin, J.H., 1996. The impact of industry shocks on takeover and restructuring activity. J. Financ. Econ. $41,193-229$.

Nadolska, A., Barkema, H.G., 2014. Good learners: How top management teams affect the success and frequency of acquisitions. Strateg. Manag. J. 35, 14831507.

Netter, J., Stegemoller, M., Wintoki, M.B., 2011. Implications of Data Screens on Merger and Acquisition Analysis: A Large Sample Study of Mergers and Acquisitions from 1992 to 2009. Rev. Financ. Stud. 24, 2316-2357.

Ployhart, R., Nyberg, A., Reilly, G., A. Maltarich, M., 2014. Human Capital Is Dead; Long Live Human Capital Resources! Journal of Management 40, 371-398. Renneboog, L., Vansteenkiste, C., 2019. Failure and success in mergers and acquisitions. J. Corp. Finance 58, 650-699.

Renneboog, L., Zhao, Y., 2011. Us knows us in the UK: On director networks and CEO compensation. J. Corp. Finance 17, $1132-1157$.

Renneboog, L., Zhao, Y., 2014. Director Networks and Takeovers. J. Corp. Finance 28, 218-234.

Renneboog, L., Zhao, Y., 2020. Director Networks, Turnover, and Appointments. European Financial Management 26 (1), $44-76$.

Tosi, H.L., Werner, S., Katz, J.P., Gomez-Mejia, L.R., 2000. How much does performance matter? A meta-analysis of CEO pay studies. J. Manag. 26, $301-339$. UK CGC, 2018. The UK Corporate Governance Code. London September 2018.

UK CGC, 2016. The UK Corporate Governance Code. Lond. Sept.

UK Companies Act, 2006. Companies Act 2006 [WWW Document]. URL

Vafeas, N., 1999. Board meeting frequency and firm performance. J. Financ. Econ. 53, 113-142.

Wang, C., Xie, F., Zhu, M., 2015. Industry Expertise of Independent Directors and Board Monitoring. Journal of Financial and Quantitative Analysis 50, 929962.

Wright, P., Kroll, M., Elenkov, D., 2002. Acquisition Returns, Increase in Firm Size. and Chief Executive Officer Compensation: The Moderating Role of Monitoring. Acad. Manage. J. 45, 599-608.

Wright, P.M., Coff, R., Moliterno, T.P., 2014. Strategic human capital: Crossing the great divide. J. Manag. 40, 353-370.

Yeo, R.K., Marquardt, M.J., 2015. (Re) Interpreting Action, Learning, and Experience: Integrating Action Learning and Experiential Learning for HRD. Hum. Resour. Dev. Q. 26, 81-107.

Zattoni, A., Cuomo, F., 2010. How Independent, Competent and Incentivized Should Non-executive Directors Be? An Empirical Investigation of Good Governance Codes. Br. J. Manag. 21, 63-79.

Zollo, M., Singh, H., 2004. Deliberate Learning in Corporate Acquisitions: Post-Acquisition Strategies and Integration Capability in U.S. Bank Mergers. Strateg. Manag. J. 25, 1233-1256. 